ENVIRONMENTAL RESTORATION PROGRAM

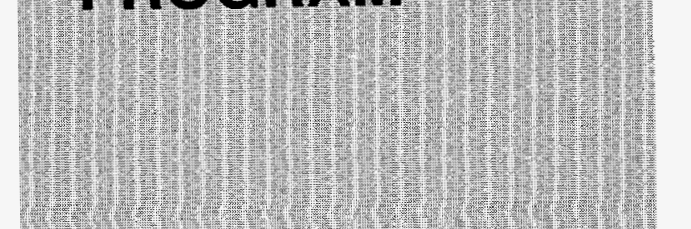

\title{
Best Management Practices Plan for the Lower East Fork Poplar Creek Remedial Action Project, Oak Ridge, Tennessee
}

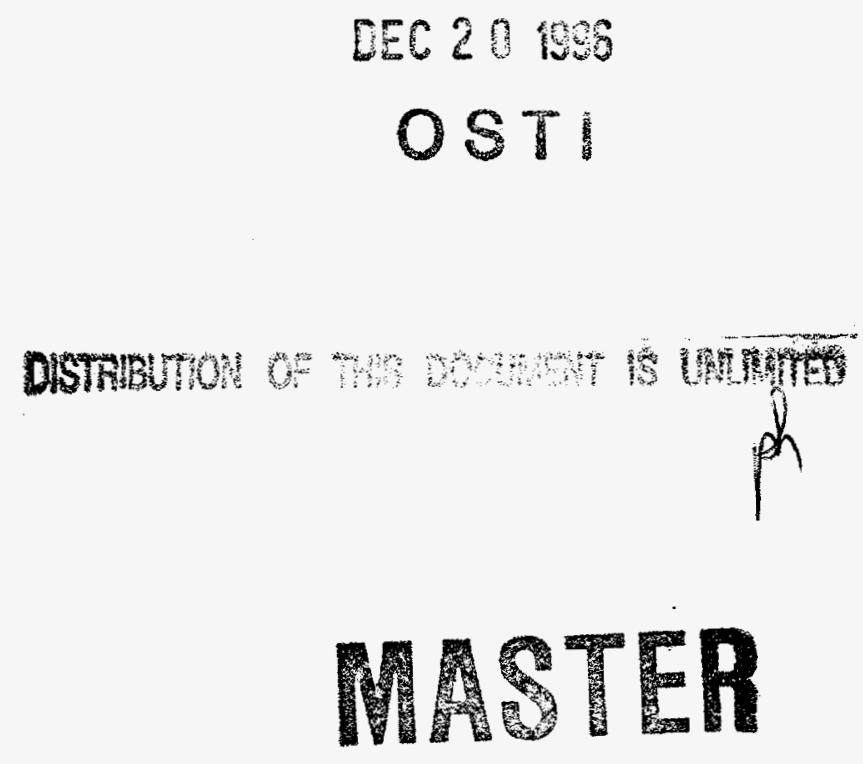

This document has been approved by the Y-12 Plant Technical Information Office for release to the public. Date: $8 / 12 / 96$ 


\section{Foster Wheeler Environmental Corporation and Science Applications International Corporation}

contributed to the preparation of this document and should not be considered eligible contractors for its review.

This report has been reproduced directly from the best available copy.

Available to DOE and DOE contractors from the Office of Scientific and Technical Information, P.O. Box 62, Oak Ridge, TN 37831; prices available from 423-576-8401 (fax 423-576-2865).

Available to the public from the National Technical Information Service, U.S. Department of Commerce, 5285 Port Royal Rd., Springfield, VA 22161. 
Energy Systems Environmental Restoration Program

Best Management Practices Plan for the Lower East Fork Poplar Creek

Remedial Action Project, Oak Ridge, Tennessee

Date Issued-August 1996

Best Management Practices Plan prepared by Foster Wheeler Environmental Corporation Oak Ridge, Tennessee under subcontract 32M-03542C

Spill Prevention and Response Plan prepared by Science Applications International Corporation Oak Ridge, Tennessee under subcontract 43B-99069C, Y05

Prepared for the U.S. Department of Energy Office of Environmental Management under budget and reporting code EW 20

Environmental Management Activities at the

OAK RIDGE Y-12 PLANT

Oak Ridge, Tennessee 37831-8169 managed by

LOCKHEED MARTIN ENERGY SYSTEMS, INC.

for the

U.S. DEPARTMENT OF ENERGY

under contract DE-AC05-84OR21400 


\section{DISCLAIMER}

Portions of this document may be illegible in electronic image products. Images are produced from the best available original document. 


\section{DISCLAIMER}

This report was prepared as an account of work sponsored by an agency of the United States Government. Neither the United States Government nor any agency thereof, nor any of their employees, make any warranty, express or implied, or assumes any legal liability or responsibility for the accuracy, completeness, or usefulness of any information, apparatus, product, or process disclosed, or represents that its use would not infringe privately owned rights. Reference herein to any specific commercial product, process, or service by trade name, trademark, manufacturer, or otherwise does not necessarily constitute or imply its endorsement, recommendation, or favoring by the United States Government or any agency thereof. The views and opinions of authors expressed herein do not necessarily state or reflect those of the United States Government or any agency thereof. 


\section{PREFACE}

This Best Management Practices Plan for the Lower East Fork Poplar Creek Remedial Action Project, Oak Ridge, Tennessee (Y/ER-260/R1) was prepared in support of the Phase II Remedial Design Report (DOE/OR/01-1449\&D2) and in accordance with requirements under the Comprehensive Environmental Response, Compensation, and Liability Act of 1980 (CERCLA) to present the plan for best management practices to be followed during the remediation. Appendix B of this document contains the Spill Prevention and Response Plan for the Lower East Fork Poplar Creek Remedial Action Project, Oak Ridge, Tennessee, which is not being released separately. This work was performed under Work Breakdown Structure 1.4.12.3.1.04, Activity Data Sheet 9304, "Lower East Fork Poplar Creek." This document provides the Environmental Restoration Program with information about the spill prevention and control, water quality monitoring, good housekeeping, sediment and erosion control, and inspections and environmental compliance practices and measures to be employed during Phase I and Phase II of the remediation project for the Lower East Fork Poplar Creek Operable Unit. 


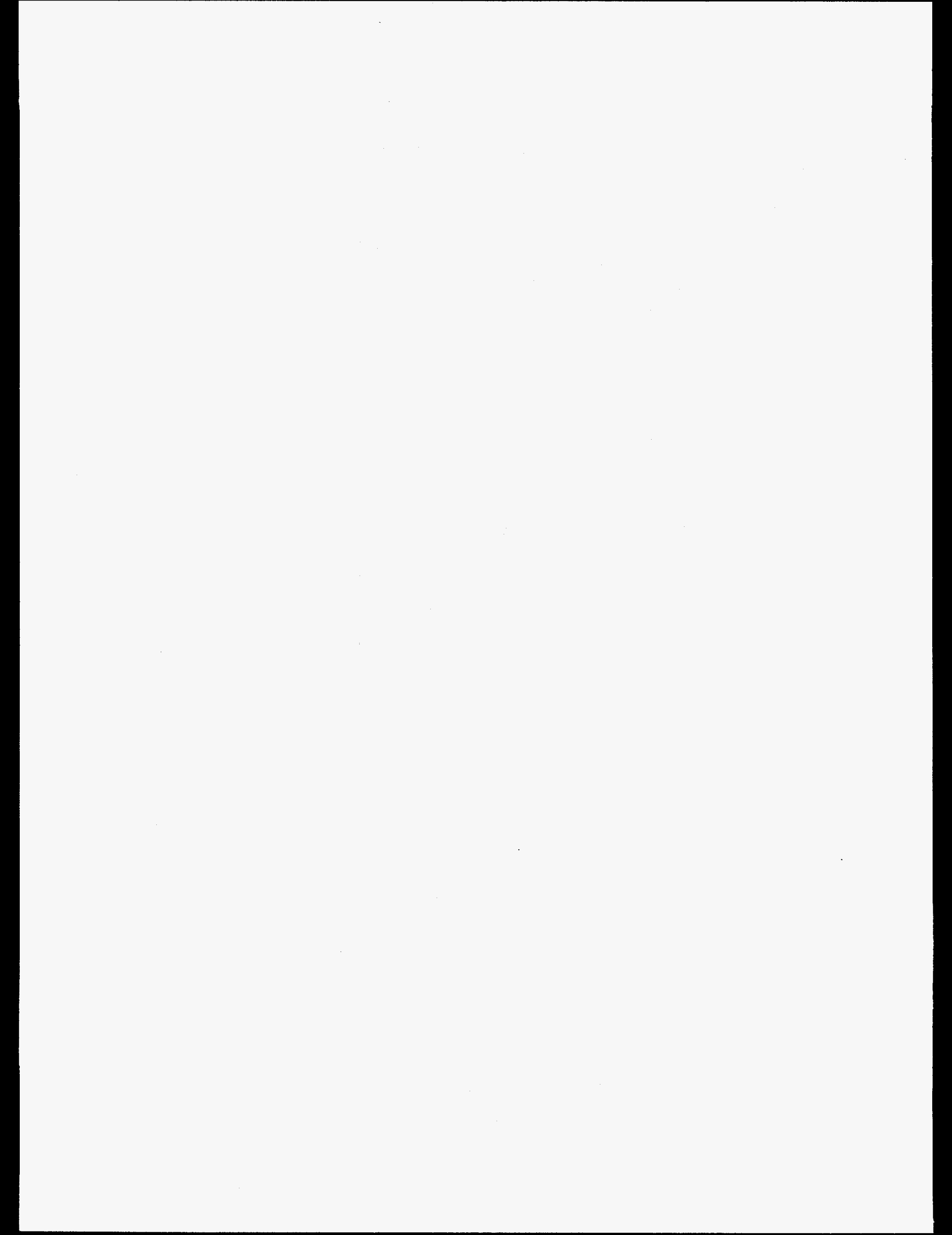




\section{CONTENTS}

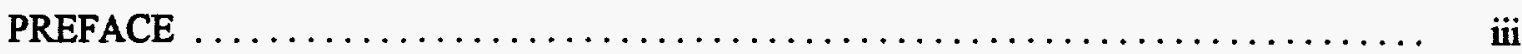

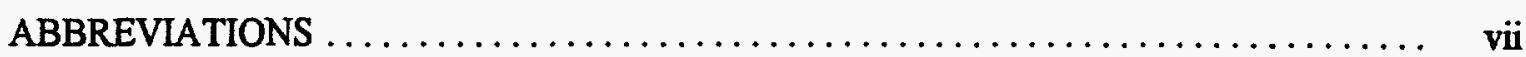

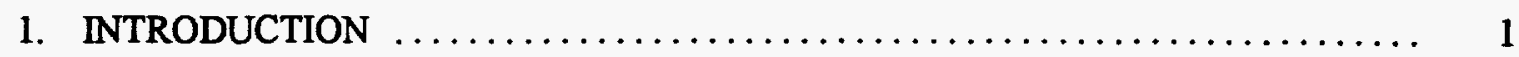

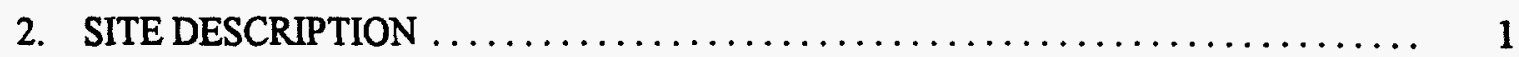

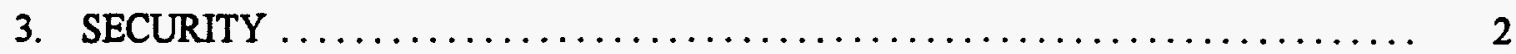

4. EMPLOYEE TRAINING $\ldots \ldots \ldots \ldots \ldots \ldots \ldots \ldots \ldots \ldots \ldots \ldots \ldots \ldots \ldots \ldots, 2$

5. PRINCIPAL SAFETY, FIRE, AND HEALTH HAZARDS $\ldots \ldots \ldots \ldots \ldots \ldots \ldots, 2$

6. SPILL PREVENTION AND CONTROL $\ldots \ldots \ldots \ldots \ldots \ldots \ldots \ldots \ldots \ldots \ldots \ldots \ldots \ldots$

7. WATER QUALITY MONITORING $\ldots \ldots \ldots \ldots \ldots \ldots \ldots \ldots \ldots \ldots \ldots \ldots \ldots \ldots$

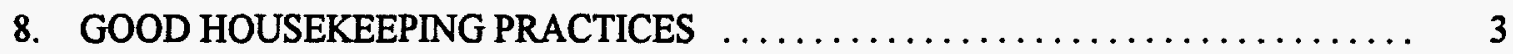

9. SEDIMENT AND EROSION CONTROL MEASURES $\ldots \ldots \ldots \ldots \ldots \ldots \ldots \ldots$

10. INSPECTIONS AND ENVIRONMENTAL COMPLIANCE $\ldots \ldots \ldots \ldots \ldots \ldots \ldots$

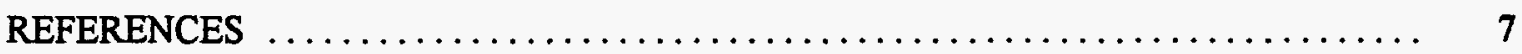

Appendix A. MAPS $\ldots \ldots \ldots \ldots \ldots \ldots \ldots \ldots \ldots \ldots \ldots \ldots \ldots \ldots \ldots \ldots \ldots \ldots \ldots \ldots \ldots$, A-1

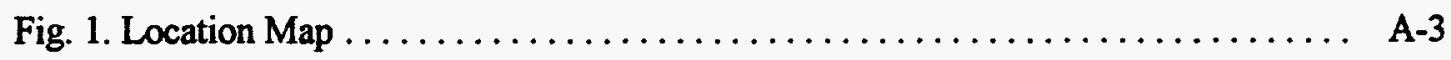

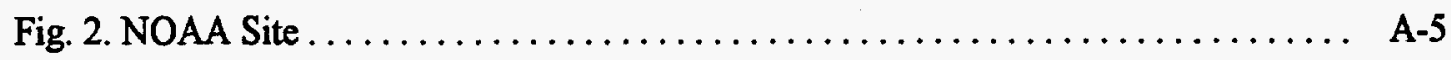

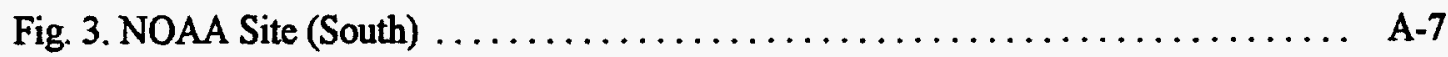

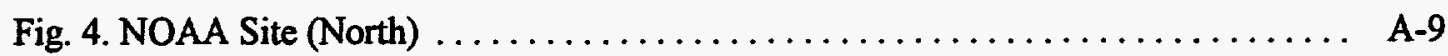

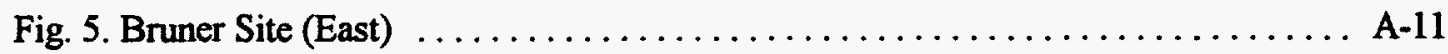

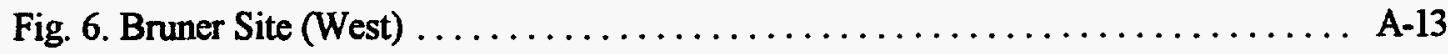

Appendix B. SPILL PREVENTION AND RESPONSE PLAN FOR THE LOWER EAST FORK POPLAR CREEK REMEDIAL ACTION PROJECT, OAK RIDGE, TENNESSEE 


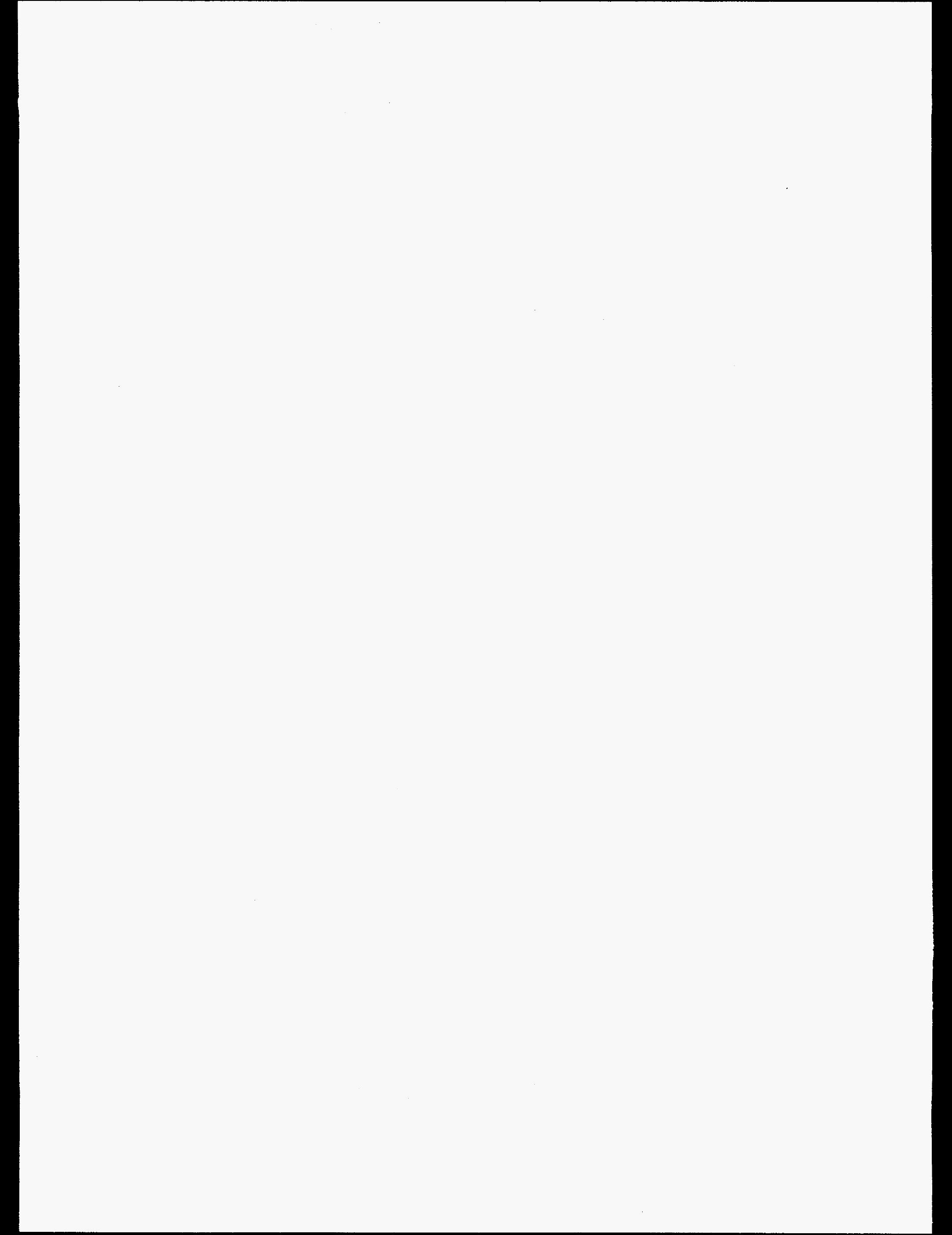




\section{ABBREVIATIONS}

BMP

CERCLA

CFC

CFR

DOE

DSWM

Energy Systems

EPA

HSEA

ILF-V

LEFPC

NFPA

NOAA

NPDES

ORNL

ORR

PSS

SPR

SSHO

TDEC
Best Management Practices Plan

Comprehensive Environmental Response, Compensation, and Liability Act certified-for-construction Code of Federal Regulations

U.S. Department of Energy

Division of Solid Waste Management

Lockheed Martin Energy Systems, Incorporated

U.S. Environmental Protection Agency

Y-12 Health, Safety, Environment, and Accountability

Industrial Landfill V, Y-12

Lower East Fork Poplar Creek

National Fire Protection Association

National Oceanic and Atmospheric Administration

National Pollutant Discharge Elimination System

Oak Ridge National Laboratory

Oak Ridge Reservation

Plant Shift Superintendent

Spill Prevention and Response Plan

Site Safety and Health Officer

Tennessee Department of Environment and Conservation 



\section{INTRODUCTION}

The U.S. Department of Energy (DOE) has three major operating facilities on the DOE Oak Ridge Reservation (ORR) in Oak Ridge, Tennessee: the Oak Ridge Y-12 Plant, the K-25 Site, and the Oak Ridge National Laboratory (ORNL) managed by Lockheed Martin Environmental Research Corporation. All facilities are managed by Lockheed Martin Energy Systems, Incorporated (Energy Systems) for the DOE.

The Y-12 Plant is adjacent to the city of Oak Ridge and is also upstream from Oak Ridge along East Fork Poplar Creek. The portion of the creek downstream from the Y-12 Plant is Lower East Fork Poplar Creek (LEFPC). This project will remove mercury-contaminated soils from the LEFPC floodplain, transport the soils to Industrial Landfill V (ILF-V), and restore any affected areas. This project contains areas that were designated in 1989 as a Comprehensive Environmental Response, Compensation, and Liability Act (CERCLA) site. The site includes DOE property and portions of commercial, residential, agricultural, and miscellaneous areas within the city of Oak Ridge.

The purpose of this document is to provide a site-specific Best Management Practices Plan (BMP) for LEFPC site remediation.

Sect. 304(e) of the Clean Water Act enables the Administrator of the U.S. Environmental Protection Agency (EPA) to control point source releases of pollutants. The National Pollutant Discharge Elimination System (NPDES) requires that facilities with the potential for releasing pollutants to the waters of the United States submit a BMP, as specified in the Code of Federal Regulations (CFR) in 40 CFR 125, Subpart K, as part of the discharge permit application.

According to the Energy Systems Environmental and Waste Management Policy,

It is company policy to establish and to maintain waste management, pollution control, and surveillance programs which are consistent with the company and DOE policy and which meet the requirements of federal, state, and local regulations to assure that installation personnel, the general public, and the environment are protected against hazardous pollutants.

Implementation of the BMP will be initiated by providing a copy to all parties involved in the LEFPC site remediation. Recurring formal site inspections will be made by the Energy Systems representative during facility construction. All site inspections will be made on a weekly basis and after storm events.

\section{SITE DESCRIPTION}

The project site consists of several individual locations of mercury-contaminated soil, shown on the maps in Appendix A. Many of the requirements in this BMP also apply to the transportation routes needed to deliver contaminated soil to the ILF-V. The permissible transportation routes are shown on the Traffic Control Plan Drawings. 
Site remediation will directly disturb approximately 2.1 acres during Phase I and 7.5 acres during Phase I, and 7.0 acres during Phase II. Site access and staging areas will disturb approximately 4.0 acres during Phase I, and 7.0 acres during Phase II.

\section{SECURITY}

Temporary barrier fencing will be installed around excavation areas. The staging area sites will be surrounded by perimeter fencing and warning signs to prevent inadvertent access by the public. The fencing will consist of a standard $6 \mathrm{ft}$ high chain-link fence. A swinging gate will be provided at the entrance. In addition to fencing, site security will be maintained by a periodic patrol during offshift periods. Security personnel will be equipped with portable phones for direct communication with the city of Oak Ridge. A periodic patrol force enhances the probability of detecting and quickly mitigating potential environmental incidents.

\section{EMPLOYEE TRAINING}

Employees will receive a broad range of environmental, health, and safety training based on their job requirements. Supervisors are responsible for providing on-the-job training with respect to hazardous materials handling and company environmental policy.

Contractors and subcontractors performing work at the LEFPC site remediation will be required to comply with DOE environmental policy, including the provisions of this BMP. Contractor foremen are responsible for their employees. All site personnel are to perform the work as specified in the certified-for-construction (CFC) drawings and specifications, and as directed by the Construction Manager.

\section{PRINCIPAL SAFETY, FIRE, AND HEALTH HAZARDS}

System and equipment selections will be sufficient to provide safe operations. Use of the latest editions of applicable codes is required. Concerns regarding potential health hazards can be directed to the Site Safety and Health Officer (SSHO).

Construction operations and general construction personnel will be subject to normal and industrial hazards, and appropriate precautions must be taken.

Construction vehicles entering public roadways will be controlled as specified on the Traffic Control Plan Drawings. 


\section{SPILL PREVENTION AND CONTROL}

The Spill Prevention and Response Plan (SPR) for the LEFPC project provides details concerning roles and responsibilities of employees. If a spill occurs at the LEFPC project site, all safe and pratical methods available will be used to prevent materials from entering streams. Spills will be reported immediately to the Construction Manager and the city of Oak Ridge.

The SPR for this project is provided in Appendix B.

\section{WATER QUALITY MONITORING}

The LEFPC project site discharges into East Fork Poplar Creek and eventually flows into the Clinch River. Water quality monitoring will be performed in accordance with the project specific Sampling and Analysis Plan for Treatment Water and Creek Water. Every effort will be made to minimize any effect construction may have on surface waters.

\section{GOOD HOUSEKEEPING PRACTICES}

Good housekeeping practices will be observed by all personnel present at the LEFPC project site at all times. Paper trash and refuse will be collected and removed on a regular basis. No unpermitted wastewater of any type will be discharged on-site. All rinse water containing additives of any sort (e.g., soap, degreasers, cleaning agents) will be collected, contained, and properly disposed of. Trucks hauling material will not be overfilled. Loose debris will be contained within the vehicles to prevent littering of highways and haul roads. Brush, construction debris, and trash will be promptly removed from drainways and streams. Brush will not be burned near streams in order to prevent residue from entering the streams.

Fueling operations will be conducted so that small fuel/oil releases are contained and cleaned up daily. Appropriate precautions are to be taken to minimize discharge of fuel, oil, lubricants, grease, and other hydrocarbons.

Tracking soils onto public roads is prohibited. Vehicles leaving construction areas will have the undercarriage, wheels, and tires cleaned as necessary to ensure that soils are not tracked onto public roads. 


\section{SEDIMENT AND EROSION CONTROL MEASURES}

Erosion is a natural phenomenon that is greatly increased by the removal of existing vegetation and earthwork activities associated with construction. Excessive erosion causes physical damage in the watershed due to increased water velocity. Unchecked sediment can increase turbidity and suffocate streambed flora and fauna under a blanket of silt. Erosion controls placed during the construction phase will minimize soil movement and will be installed as early as possible during the construction phase.

A primary concern of this BMP is to provide erosion and sediment control measures. Several excellent references are available (Sect. 11) for additional information and guidance. All site work must conform to the CFC drawings and specifications and as directed by the Construction Manager. Deviations from the design require prior authorization from the appropriate party. project:

Several actions to lessen the environmental impact due to erosion will be taken during the

- Every effort will be made to keep disturbed areas to a minimum. Habitat disturbance will be minimized during clearing.

- Existing vegetation will not be destroyed, removed, or disturbed more than 20 calendar days prior to grading. Temporary soil stabilization materials will be applied within 5 days to all areas where grading activities have temporarily ceased and it is not anticipated to resume within 15 calendar days, unless approval is obtained from the Construction Manager.

- Scheduled earthwork activities will be adjusted based on probable weather conditions to minimize work performed during inclement weather. All reasonable attempts will be made to ensure excavated areas are promptly backfilled and are not left open between shifts or during periods of precipitation.

- Existing natural drainage will be maintained where possible to avoid disturbing off-site areas.

- Contaiminated soils shall not be stockpiled. Contaminated soils which meet the waste acceptance criteria shall be transported to the ILF-V landfill for disposal. Contaminated soils that do not meet the waste acceptance criteria shall be left in place or conditioned by dewatering.

- The LEFPC remediation site contains several drainageways which convey storm water runoff during storm events. To prevent water from ponding upstream of temporary roadways and to minimize impacts to drainways, temporary culvert-type crossings will be installed.

- There are islands located at both the National Oceanic and Atmospheric Administration (NOAA) and Bruner sites which will require excavation during Phase II. Methods of accomplishment and types of equipment used will be requested from the Contractor for approval.

- Excavation of stream banks will employ techniques which minimize impacts to streams as indicated on the CFC drawings and specifications, and as directed by the Construction Manager. 
- Straw bale barriers will be used in wet weather conveyance channels as shown on the CFC drawings.

- Silt fence shall be installed in locations shown on the CFC drawings and as directed by the Construction Manager.

- Temporary storm drain inlets and outlets will be protected with riprap.

- Topsoil shall be placed within 3 days following completion of construction activities within an area unless conditions prevent satisfactory completion of work.

- Disturbed areas will be seeded or sodded within 5 days of spreading topsoil unless directed otherwise by the Construction Manager. All seeded areas will be covered promptly with erosion control blankets.

- Overseeding or reseeding will be performed as required until vegetation is established, including fertilizing when necessary. Temporary seeding will be provided in accordance with the CFC specifications.

- Temporary erosion and sediment control measures will be in place and functional before grading operations begin, maintained throughout the construction period and repaired, if necessary, after rainfall. Temporary measures may be removed at the beginning of the workday, but must be replaced at the end of the workday.

- Remediation of problems identified in the weekly site inspection will be completed in a timely manner.

\section{INSPECTIONS AND ENVIRONMENTAL COMPLIANCE}

Weekly site inspections of the LEFPC project site during construction activities will be made by the Construction Manager to confirm compliance with policies set forth in this BMP. A written record, including the date and findings of the inspection and notification of the appropriate parties will be kept in the office of the Construction Manager.

Items to be inspected include, but are not limited to, the following:

- Field Construction Activities

-Recontouring of drainways,

-Installation of erosion control blankets,

-Positive storm water drainage, and

-Stream bank excavation. 
- Condition of Erosion Control

-Silt fences,

-Drainageways,

- Temporary storm drains,

-Riprap,

-Gully formation,

-Areas needing seeding or reseeding,

-Erosion control blankets,

-Straw bales, and

-Access roads;

- Other inspections as outlined in the SPR for Lower East Fork Poplar Creek.

Periodic site inspections during construction and operation will be made by project personnel to confirm compliance with all environmental regulations and policies, including those set forth in this BMP.

Conditions noted which require corrective action will be reported to the Construction Manager for repair. 


\section{REFERENCES}

Tennessee Erosion and Sediment Control Handbook. July 1992. Tennessee Department of Environment and Conservation.

Virginia Erosion and Sediment Control Handbook. Third Edition. 1992. Virginia Department of Conservation and Recreation.

Guidance for Erosion and Sediment Control Measures Applicable to Construction Projects at the Y-12 Plant. May 1991. Y/SUB/91-57431C/1. Martin Marietta Energy Systems, Inc. Oak Ridge, Tennessee. 
Appendix A

MAPS 


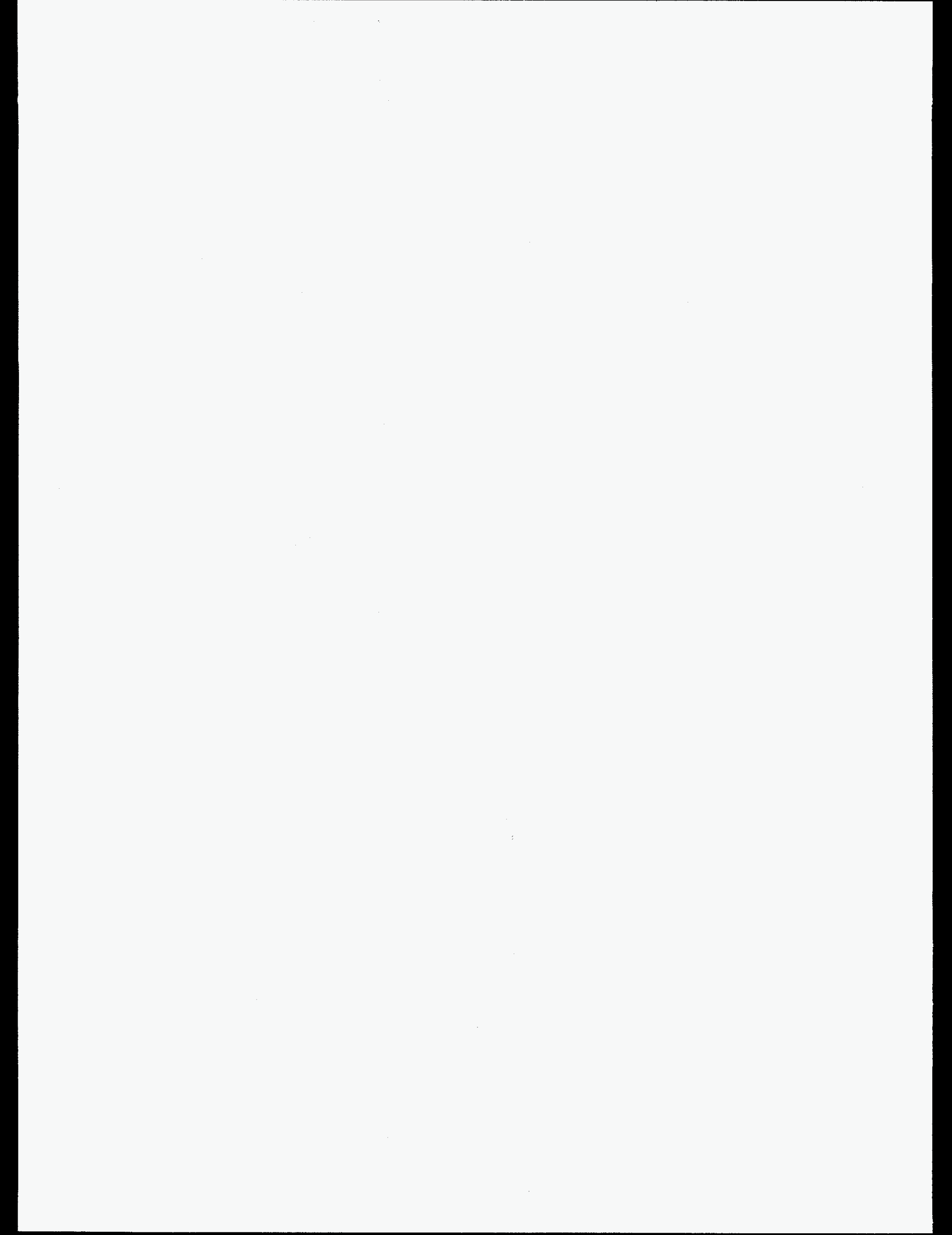


A-3

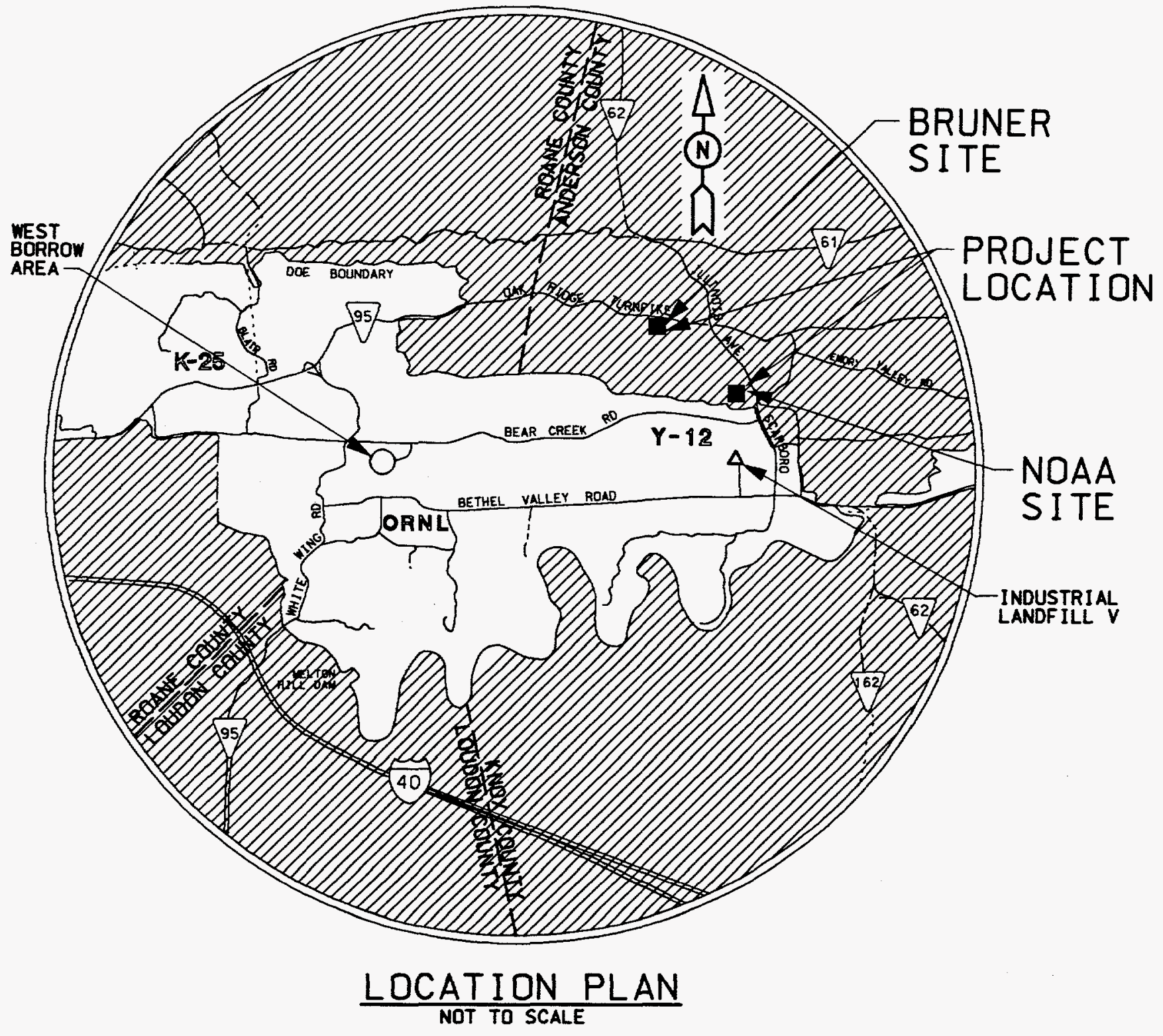

LOWER EAST FORK POPLAR CREEK REMEDIAL ACTION. PHASE I \& II 


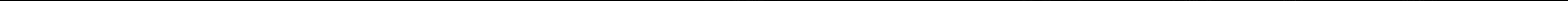




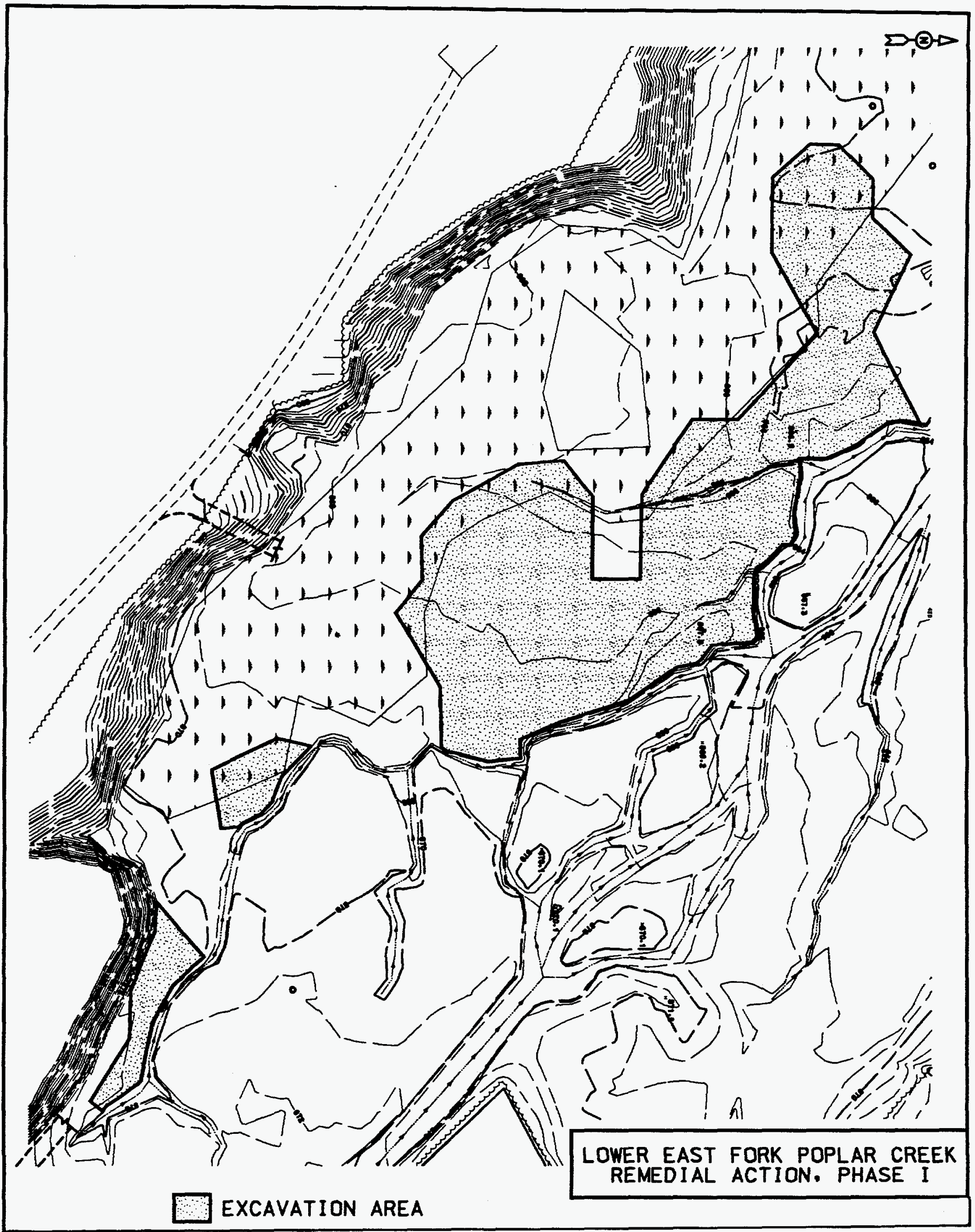

Fig. 2. NOAA Site, Phase I. 


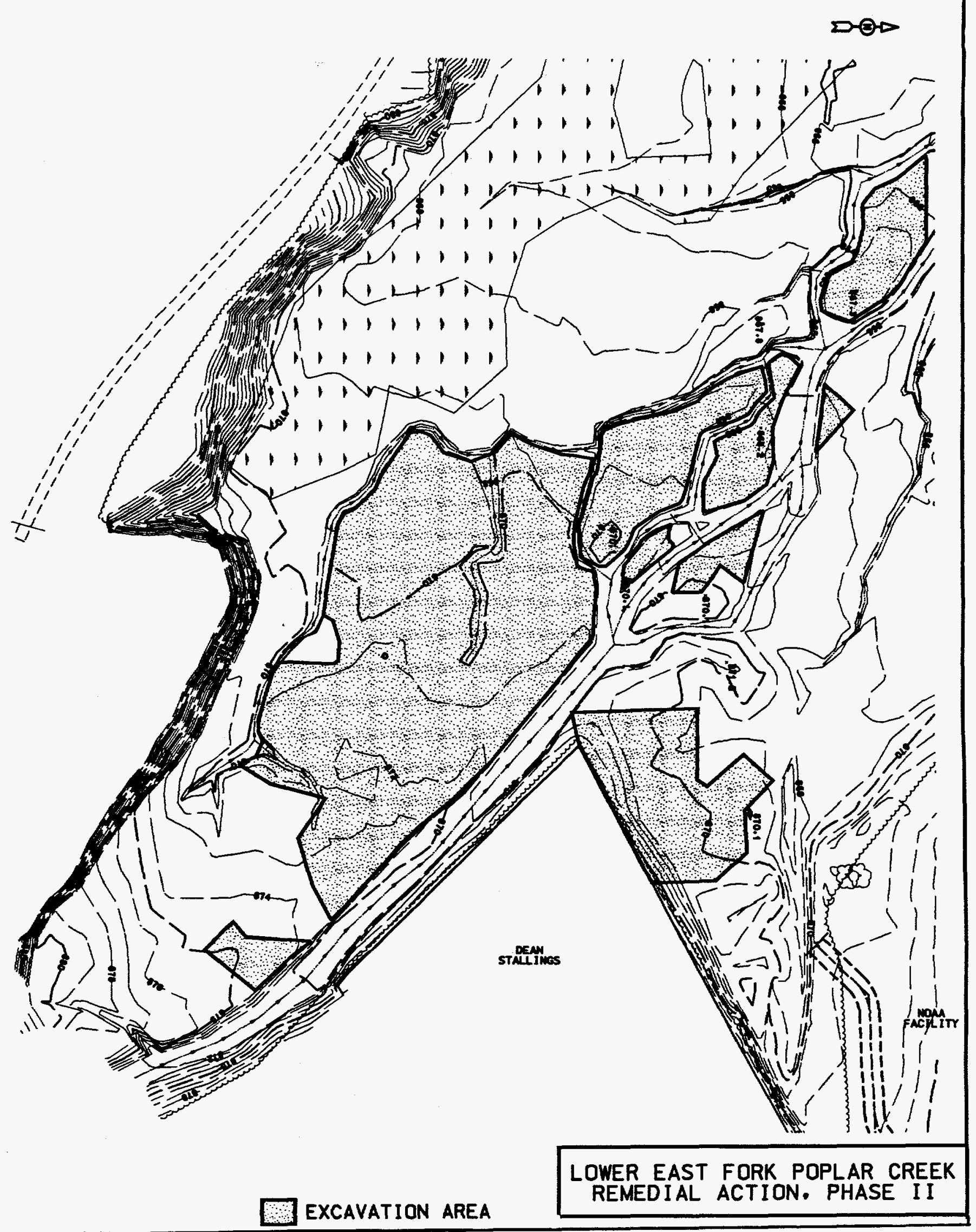

Fig. 3. NOAA Site South, Phase II. 


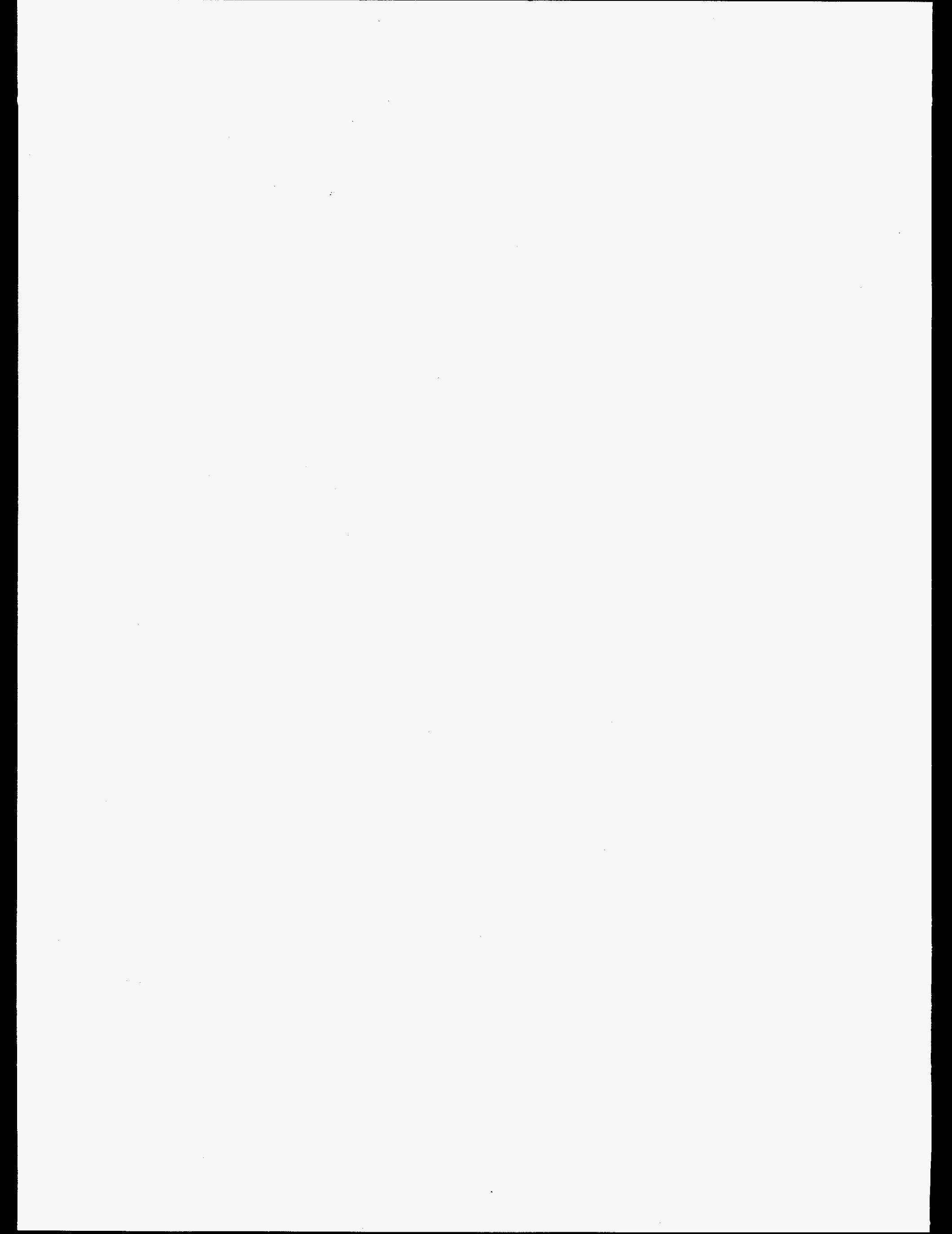




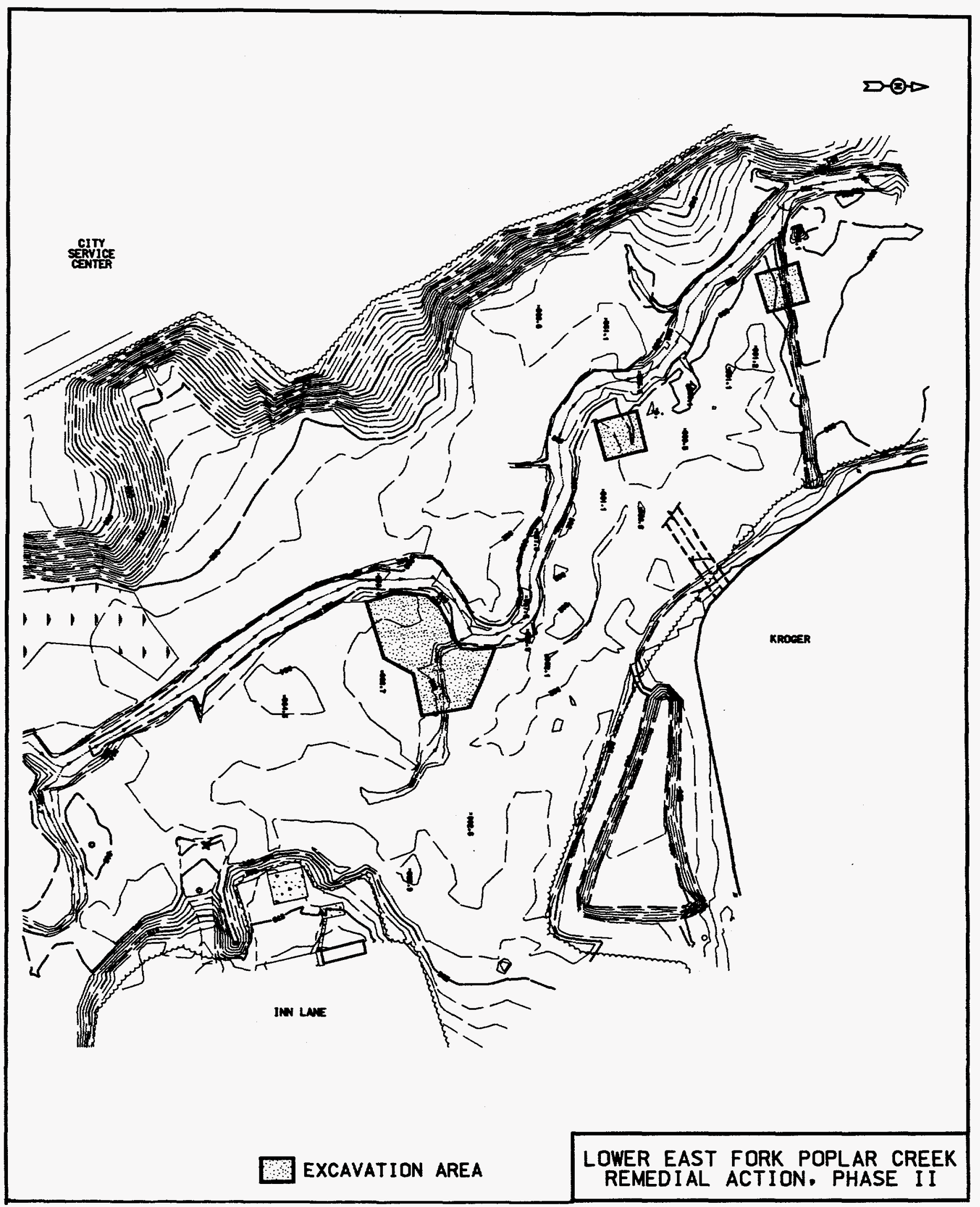

Fig. 4. NOAA Site North, Phase II. 


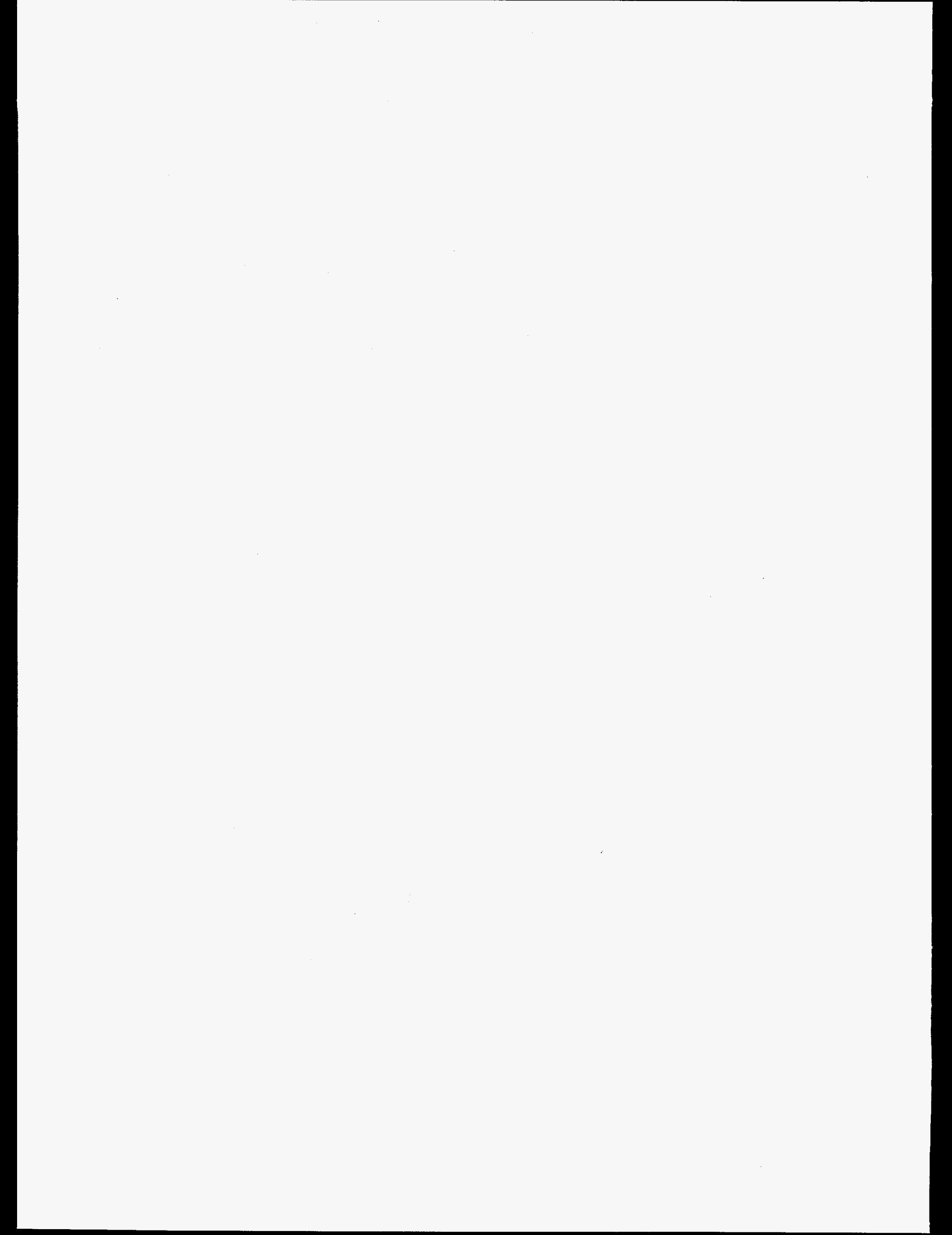




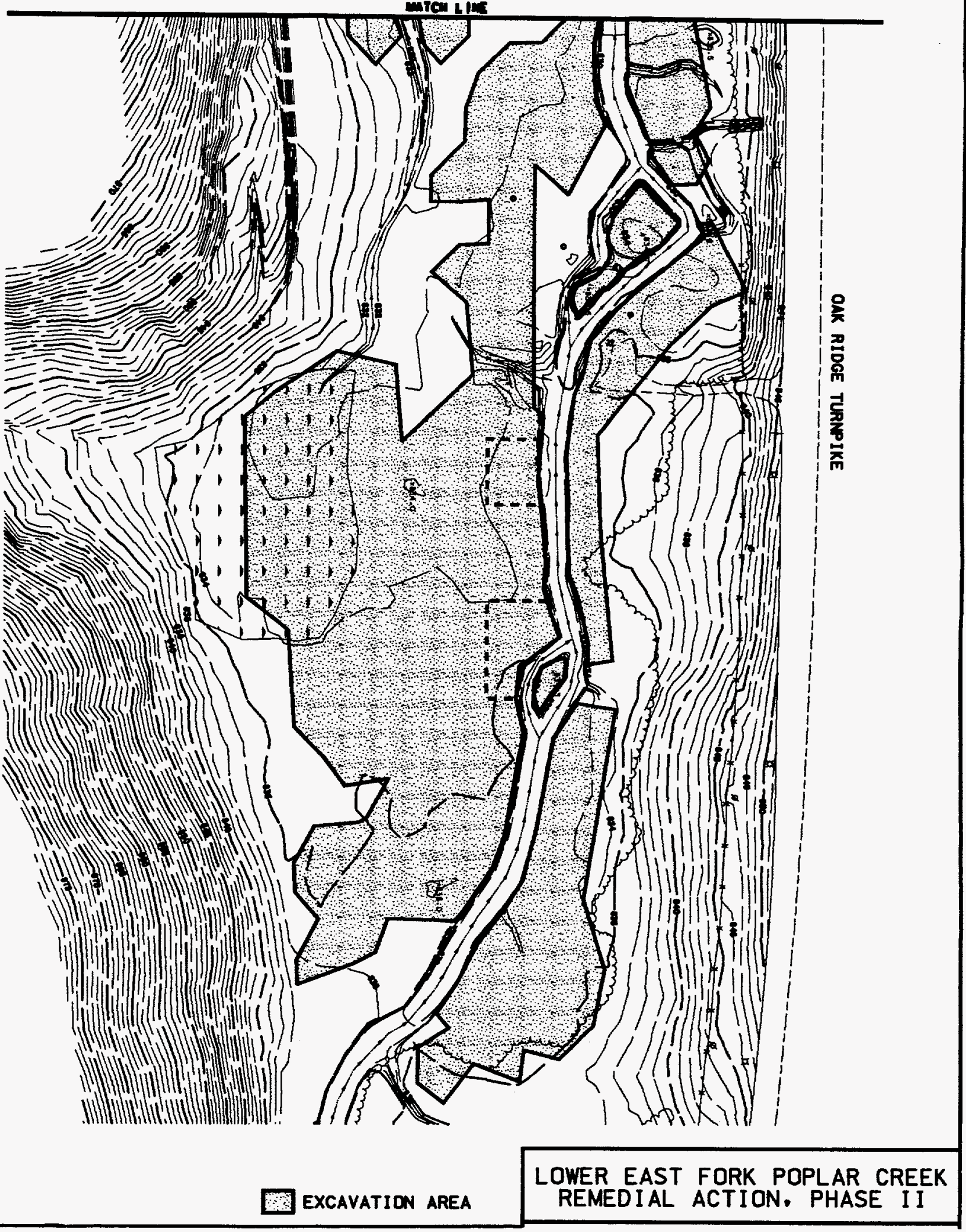

Fig. 5. Bruner Site East, Phase II. 


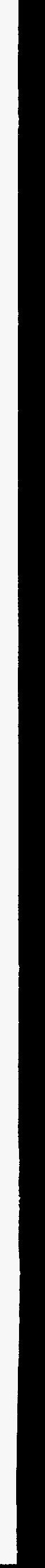




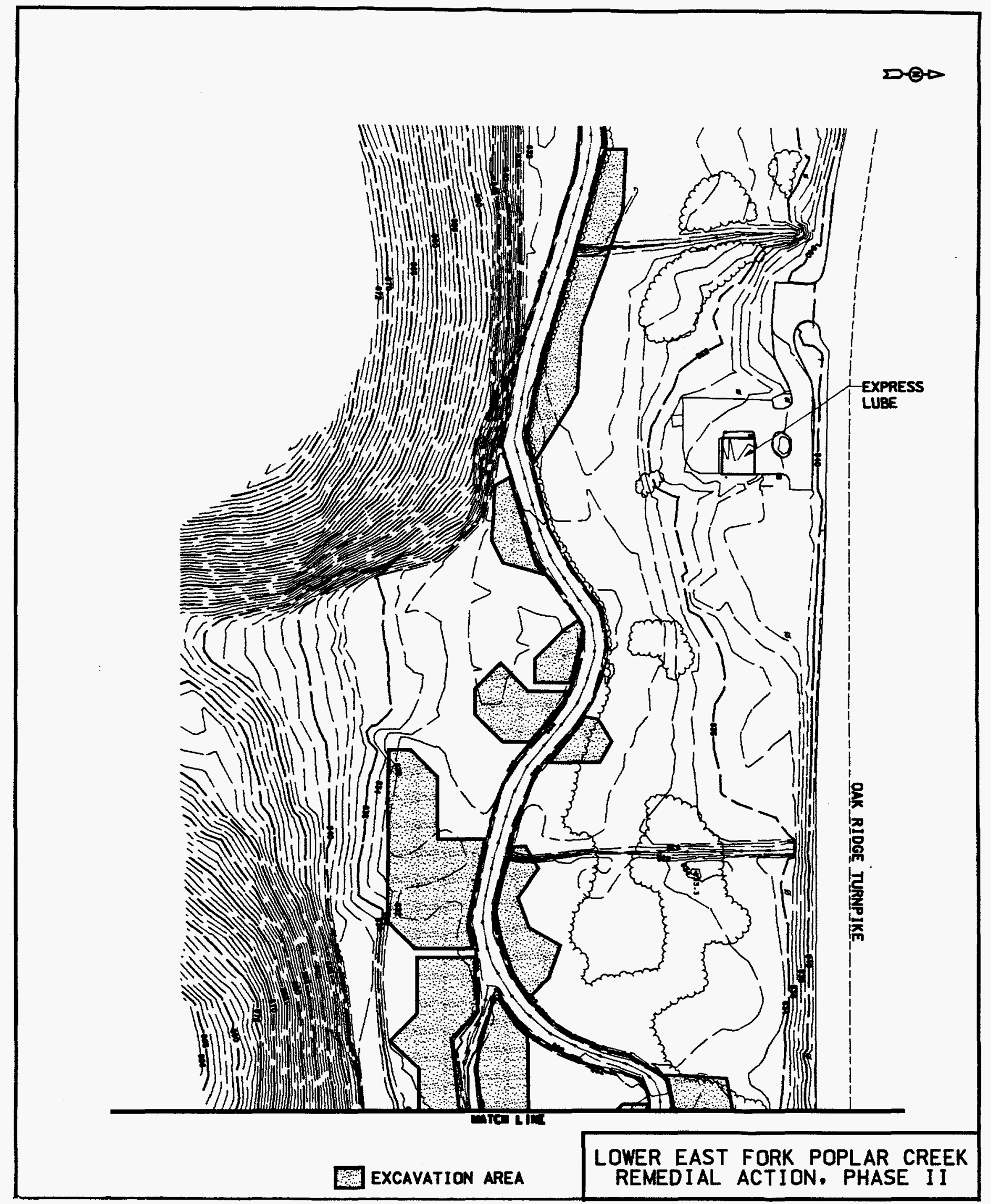

Fig. 6. Bruner Site West, Phase II. 


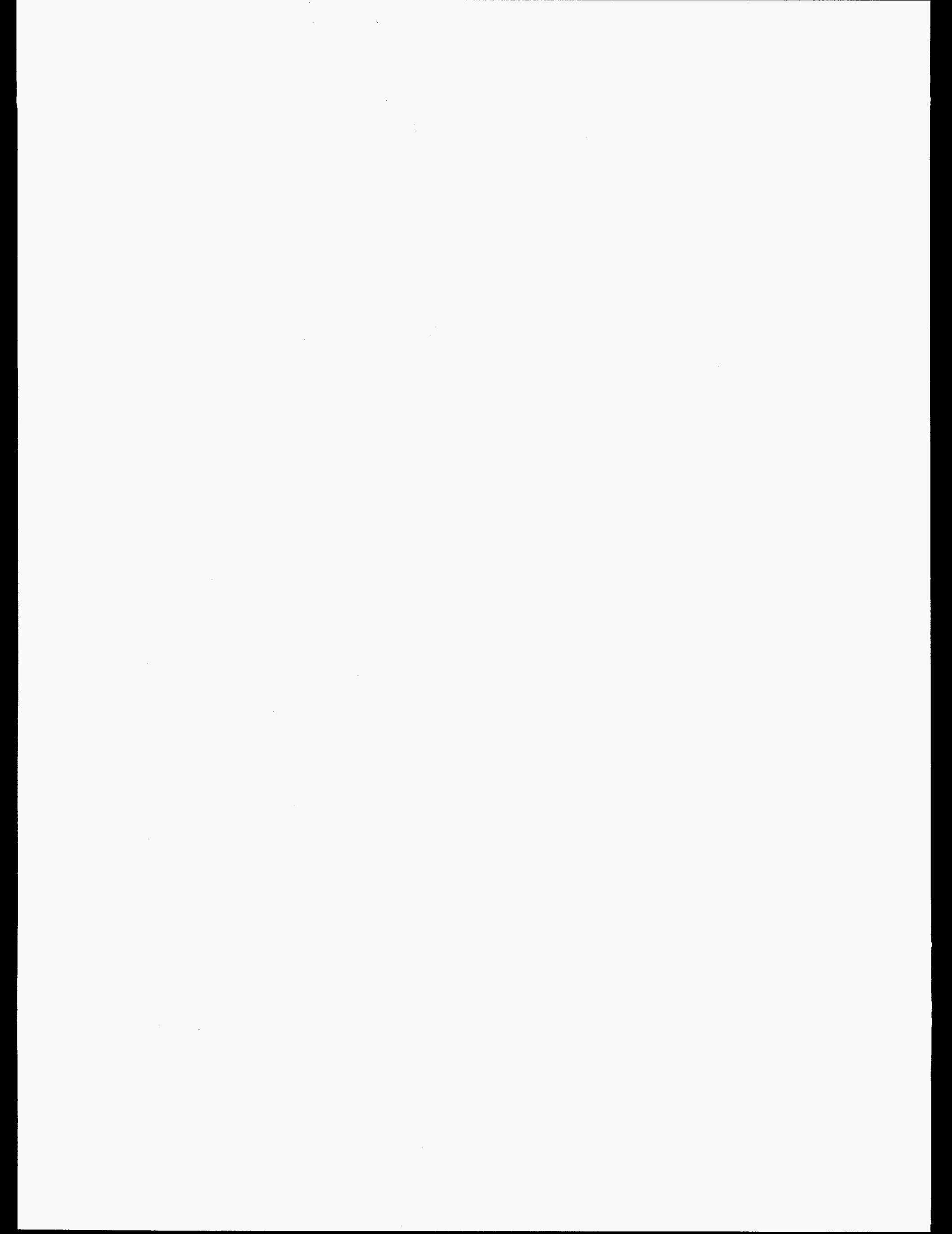


Appendix B

SPILL PREVENTION AND RESPONSE PLAN FOR THE LOWER EAST FORK POPLAR CREEK REMEDIAL ACTION, OAK RIDGE, TENNESSEE 



\section{CONTENTS}

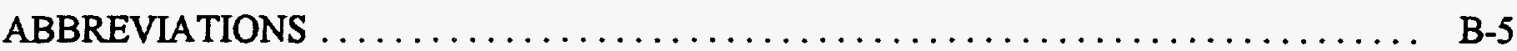

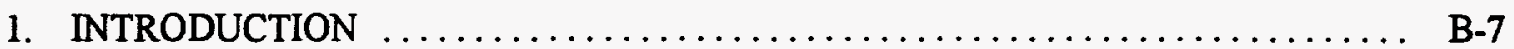

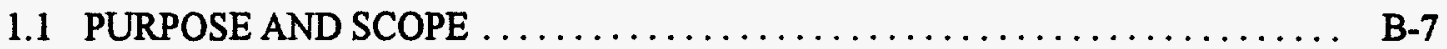

2. SPILL PREVENTION AND CONTROL REQUIREMENTS $\ldots \ldots \ldots \ldots \ldots \ldots \ldots$ B-9

2.1 IDENTIFICATION OF POTENTIAL SPILL SOURCES $\ldots \ldots \ldots \ldots \ldots \ldots \ldots$ B-9

2.2 SPILL PREVENTION MEASURES $\ldots \ldots \ldots \ldots \ldots \ldots \ldots \ldots \ldots \ldots \ldots \ldots$ B-13

2.2.1 Spill Prevention Measures for Storage and Dispensing of POL Products and Hazardous Materials from Containers . . . . . . . . . . . . . B-13

2.2.2 Spill Prevention Measures for the Tank Storage of POL Products ........ B-15

2.2.3 Spill Prevention Measures for Wastewater Management Activities ....... . B-18

2.2.4 Spill Prevention Measures for Accumulation of Hazardous Wastes . . . . . . . B B-20

2.2.5 Spill Prevention Measures for Miscellaneous Operations ............. B-22

2.3 SPILL CONTROL AND CONTAINMENT REQUIREMENTS $\ldots \ldots \ldots \ldots \ldots$ B-23

2.3.1 Secondary Containment Requirements for Container Storage . . . . . . . . . B-23

2.3.2 Secondary Containment Requirements for Tank Systems . . . . . . . . . . B-24

3. OIL AND HAZARDOUS SUBSTANCES RESPONSE PLAN $\ldots \ldots \ldots \ldots \ldots \ldots \ldots$ B-26

3.1 CONDITIONS OF IMPLEMENTATION $\ldots \ldots \ldots \ldots \ldots \ldots \ldots \ldots \ldots \ldots \ldots \ldots \ldots$

3.2 ORGANIZATIONAL AUTHORITIES AND RESPONSIBILITIES $\ldots \ldots \ldots \ldots$ B-27

3.2.1 Organization Responsibilities for Pre-Response Activities . . . . . . . . . . . . B-27

3.2.2 Organizational Authorities and Responsibilities for Response Activities . . . . . . B B-29

3.2.3 Organizational Authorities and Responsibilities for Post-Incident Activities . . . . B-32

3.3 INITIAL NOTIFICATION PROCEDURES $\ldots \ldots \ldots \ldots \ldots \ldots \ldots \ldots \ldots$ B-34

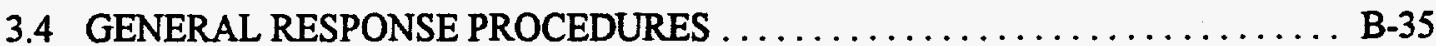

3.5 GENERAL REMEDIATION AND RESTORATION PROCEDURES $\ldots \ldots \ldots \ldots$ B-36

3.6 RELEASE REPORTING REQUIREMENTS $\ldots \ldots \ldots \ldots \ldots \ldots \ldots \ldots \ldots \ldots$ B-37

4. PERSONNEL TRAINING REQUIREMENTS $\ldots \ldots \ldots \ldots \ldots \ldots \ldots \ldots \ldots \ldots \ldots$ B-38

4.1 GENERAL SPILL PREVENTION AND RESPONSE TRAINING . . . . . . . B-38

4.2 TRAINING PROGRAM REQUIREMENTS $\ldots \ldots \ldots \ldots \ldots \ldots \ldots \ldots \ldots \ldots$ B-38 



\section{ABBREVIATIONS}

AOC

ASME

ASTM

CERCLA

CFR

CRZ

CWA

DOE

EFPC

EM

EPA

FML

FRP

HAZMAT

HDPE

HSEA

HRT

IC

ILF-V

LEPC

LEFPC

LMES

MK-F

NFPA

NOAA

NPDES

NRC

ORFD

ORPD

ORNL

ORR

OU

POL

POTW

PPE

PSS

PVC area-of-concern

American Society of Mechanical Engineers

American Society for Testing and Materials

Comprehensive Environmental Response, Compensation, and Liability Act Code of Federal Regulations

contamination reduction zone

Clean Water Act

U.S. Department of Energy

East Fork Poplar Creek

Environmental Manager

U.S. Environmental Protection Agency

flexible membrane liner

fiberglass reinforced plastic

hazardous material

high-density polyethylene

Y-12 Health, Safety, Environment, and Accountability

HAZMAT Response Team

incident commander

Industrial Landfill V, Y-12

Local Emergency Planning Committee

Lower East Fork Poplar Creek

Lockheed Martin Energy Systems, Incorporated

MK Ferguson of Oak Ridge Company

National Fire Protection Association

National Oceanic and Atmospheric Administration

National Pollutant Discharge Elimination System

National Response Center

Oak Ridge Fire Department

Oak Ridge Police Department

Oak Ridge National Laboratory

Oak Ridge Reservation

Operable Unit

petroleum, oil, and lubricant

privatele owned treatment work

personal protective equipment

Plant Shift Superintendent

polyvinylchloride 
RA

RCRA

ROD

RQ

SCUT

SFO

SPCC

SPR

SSHO

SRC

TDEC

TEMA

TSDF

TPQ

UL

WMD
Remedial Action

Resource Conservation and Recovery Act

Record of Decision

reportable quantity

Spill Clean-up Team

senior fire official

Spill Prevention Control and Countermeasures Plan

Spill Prevention and Response Plan

Site Safety and Health Officer

Spill Response Coordinator

Tennessee Department of Environment and Conservation

Tennessee Emergency Management Agency

hazardous waste treatment, storage, and disposal facility

threshold planning quantity

Underwriters' Laboratories, Inc.

Waste Management Division 


\section{INTRODUCTION}

\subsection{PURPOSE AND SCOPE}

The Lower East Fork Poplar Creek (LEFPC) Operable Unit (OU) is a Comprehensive Environmental Response, Compensation, and Liability Act (CERCLA) site that consists of $\sim 14.5 \mathrm{mi}$ of floodplain soils and sediments contaminated with mercury from historical operations at the Y-12 Plant. The selected remedy for this OU, as defined by the final Record of Decision (ROD) in 1995 involves excavation of the floodplain soils contaminated with greater than $400 \mathrm{ppm}$ of mercury and disposal of this media at a secure, lined, landfill at Y-12. In accordance with the ROD, the U.S. Department of Energy (DOE) is currently planning to remove $\sim 26,500 \mathrm{yd}^{3}$ of contaminated soil from the two floodplain areas that exceed the remediation goal. These remedial actions will be conducted in two phases, with the initial phase consisting of removal of $\sim 4000 \mathrm{yd}^{3}$ of soil from the NOAA site in July and August 1996. The Phase I activities will be conducted by a subcontractor to MK Ferguson of Oak Rige Company (MK-F) under their supervision and oversight by Lockheed Martin Energy Systems (LMES). Phase II of the remedial action, scheduled for 1997, will involve completion of remedial activities at the NOAA site and excavation and restoration of the Bruner site. As currently planned, the Phase II activities will be conducted by a sub-contractor to MK-F under their supervision and LMES oversight.

A number of ancillary operations and services will be necessary to support the primary remedial actions including:

- short-term accumulation of excavated soils, landscaping wastes, and debris for soil dewatering or staging prior to transport to $\mathrm{Y}-12$;

- accumulation of any hazardous wastes discovered in the floodplain (i.e. paints, solvents, aerosol cans, batteries);

- storage of untreated and treated wastewater;

- wastewater treatment;

- accumulation of wastewater treatment residues;

- establishment of a field operations center;

- delineation of a contamination reduction zone (CRZ) for field personnel;

- establishment of field analytical services;

- storage of materials necessary for implementation of the remedial actions (topsoil, lime, fertilizer, seed, erosion control blankets, silt fencing, gravel, etc.);

- $\quad$ set-up of refueling operations;

- $\quad$ set-up mechanical servicing operations (i.e. brake fluids, transmission fluids, hydraulic fluids, oils) for heavy equipment;

- establishment of a field maintenance depot;

- provision of basic utility services (potable water, electrical generators); and

- storage of fuels and lubricants for the gasoline powered field pumps and electrical generators.

For Phase I the fueling and servicing operations will be provided by mobile facilities on an as needed basis. These services/operations will generally be located and performed in the staging area 
at the NOAA site except for fueling of the excavation equipment which will be performed in temporary CRZs established along the exclusion zone boundaries as required. For Phase II the Construction Subcontractor will have discretion as to whether these services will be provided by mobile or temporary fixed facilities set-up in the NOAA and Bruner staging areas (depot type operations). It is currently anticipated that the Phase II subcontractor will also utilize mobile service facilities set-up in the NOAA and Bruner staging areas on an as needed basis (except for fueling of the excavations equipment which will be performed in temporary CRZs established along the exclusion zone as required). However, this Spill Prevention and Response Plan (SPR) provides requirements for both mobile facilities operating in the stationary mode (i.e., fuelers and oilers) and temporary fixed facilities (field depots) in order to address both options.

Under 40 Code of Federal Regulations (CFR) 112, any facility that has a reasonable probability for a release or accidental discharge of oil to the surface waters of the United States is required to develop a Spill Prevention Control and Countermeasures (SPCC) Plan. The requirements of 40 CFR 112 also apply to mobile fueling facilities that are not used for interstate or intrastate commerce while such units are operating in the stationary mode. Similar provisions pertaining to potential releases of hazardous substances are required for National Pollutant Discharge Elimination System (NPDES) permitted facilities under 40 CFR 125 Subpart $\mathrm{K}$ and proposed 40 CFR 151 . The Resource Conservation and Recovery Act (RCRA) requires fully regulated generators to comply with personnel training (40 CFR 265.16), emergency preparedness (40 CFR 225 Subpart C) and contingency plan (40 CFR 265 Subpart D) requirements for accumulation of hazardous waste for less than 90 days. Although the LEFPC OU is exempt from permitting and other administrative standards under CERCLA Sect. 121(e), the substantive requirements (design and operating standards) of these regulations are applicable to remedial actions conducted within the area-of-concern (AOC). Accordingly, this SPR defines minimum technical requirements for spill prevention and containment during the Phase I and Phase II remedial actions at LEFPC. Response actions to be taken for spill response and remediation are also addressed by this plan.

The Phase I and II remedial actions for LEFPC are expected to be of $\sim 12$ months duration and this SPR addresses the currently anticipated activities. However, this SPR will be revised, as necessary, to address the following situations:

- when the remedial design or its implementing procedures change in such a manner as to increase the spill potential in the LEFPC OU,

- when the response organization, procedures or equipment changes,

- when the plan fails or proves to be ineffective in the prevention of or response to a spill event.

Any revisions or amendments to this SPR shall be properly documented and maintained in accordance with the configuration control requirements of the project. 


\section{SPILL PREVENTION AND CONTROL REQUIREMENTS}

This chapter identifies potential spill sources associated with the LEFPC RA and provides minimum design and operating standards for compliance with 40 CFR 112, 40 CFR 125K and relevant 40 CFR 265 standards. The requirements provided in this chapter are intended to address both Phase I and Phase II remedial actions. As previously indicated, many of the Phase I activities that represent spill potential are mobile operations set up in the NOAA staging area on an as needed basis (daily or weekly). It is unknown whether the Phase II subcontractor will use this mode of operation or short term fixed (depot-level) facilities for service activities during the Phase II. Accordingly, this plan addresses both fixed storage and transfer facilities and similar mobile operations (when stationary).

\subsection{IDENTIFICATION OF POTENTIAL SPILL SOURCES}

Under 40 CFR 112.7(a), SPCC Plans are required to document any spills that have occurred at the operation within the previous twelve months. The cause of these previous releases and the preventive measures taken to prevent their recurrence must also be described in the plan. As previously indicated, Phase I remedial actions are currently scheduled to begin in July 1996 and Phase II activities are scheduled for initiation in late 1996. Accordingly no spill history exists for the LEFPC remedial actions by which "lessons learned" may be incorporated in this plan.

Although previous releases are not evaluated in this plan, several common causes of spills are described in this chapter in order to identify the factors that it should address. The primary causes of spills are mechanical failures, control systems failures, and poor operating practices. Examples of these types of conditions include:

- inadequate wall thickness in tanks or piping;

- inadequate structural support for a tank system that results in its collapse or failure along its bottom;

- inadequate pipe supports that result in releases due to structural failure, abrasion or thermal and vibratory stresses;

- improper materials selection;

- the absence of level indicators or switches;

- failure to periodically calibrate or test level controls leading to tank overfilling due to erroneous output;

- spills occurring during pressurized transfer operations due to the absence of controls on the discharge side of pumps that detect seal failure;

- the absence of flow or flow totaling instrumentation in transfer operations resulting in overfilling the receiving vessel;

- the absence of isolation valves in piping and process systems resulting in releases during maintenance or change-out operations;

- failure to gauge vessels (containers or tanks) prior to material transfers;

- storage of containers holding volatile materials in direct sunlight which results in over pressurization;

- storage of containers in unstable configurations that are readily overturned; 
- storage of containers in an open condition;

- failure to properly secure a receiving vessel (i.e. container) during transfer operations that results in spillage due to its movement;

- storage of containers with inadequate aisle space that results in overturning or rupturing the dnums from contact with motorized equipment;

- insufficient inspection of piping or hoses that results in spillage from the use of deteriorated equipment; and

- failure to properly isolate and drain system components and lines for maintenance or in-process change-outs.

In order to define appropriate spill prevention and control measures for the LEFPC remedial activities, the above types of conditions must be considered with respect to the potential spill sources that may exist during the project. For both Phase I and Phase II remedial actions in the LEFPC OU the primary activities/areas of concern include:

- excavation and restoration activities involving heavy equipment;

- wastewater generation from dewatering of excavation zones, decontamination of equipment, and soil drying;

- storage of petroleum, oil, and lubricant (POL) products for fueling and servicing of equipment;

- transfer of POL products;

- hazardous material storage, as necessary, for equipment maintenance;

- field maintenance operations;

- wastewater collection and treatment;

- accumulation of any hazardous wastes discovered in the floodplain;

- staging of excavated soils, landscaping wastes and debris; and

- storage of the materials necessary for restoration activities.

Table 2.1 identifies specific release sources for each of these areas/activities of concern. The spill potential for each of these release sources, in terms of location and the types and quantities of materials that may be released, are also presented in Table 2.1. Specific locations for the various release sources in the OU can not be defined because of the nature of the remedial activities, and therefore, the sources are identified as being present in the field or staging area. 
B-11

Table 2.1 Potential spill sources for Phase I and Phase II Remedial Actions at LEFPC

\begin{tabular}{|c|c|c|c|c|}
\hline $\begin{array}{l}\text { Activity/A rea of } \\
\text { Concern }\end{array}$ & $\begin{array}{l}\text { Potential Spill } \\
\text { Source }\end{array}$ & Location & Type of Material & $\begin{array}{l}\text { Potential } \\
\text { Quantity } \\
\text { Released }\end{array}$ \\
\hline $\begin{array}{l}\text { 1. Excavation/ } \\
\text { Restoration }\end{array}$ & $\begin{array}{l}\text { Leakage/Failure of } \\
\text { lines, hoses, seals on } \\
\text { trucks or equipment }\end{array}$ & In field & $\begin{array}{l}\text { Lubricating oil; brake, } \\
\text { transmission, hydraulic } \\
\text { fluids; antifreeze }\end{array}$ & $<15$ gal \\
\hline \multirow[t]{3}{*}{$\begin{array}{l}\text { 2. Wastewater } \\
\text { Generation }\end{array}$} & $\begin{array}{l}\text { Dewatering } \\
\text { excavations with gas } \\
\text { powered pumps }\end{array}$ & In field & $\begin{array}{l}\text { Wastewater; } \\
\text { Gasoline; } \\
\text { Lubricating oil }\end{array}$ & $\begin{array}{r}1000 \mathrm{gal} \\
10 \mathrm{gal} \\
<1 \mathrm{gal}\end{array}$ \\
\hline & $\begin{array}{l}\text { Transport truck } \\
\text { decontamination }\end{array}$ & In field & $\begin{array}{l}\text { Wastewater oils; } \\
\text { Diesel fuel, oil }\end{array}$ & $\begin{array}{l}600 \mathrm{gal} \\
<30 \mathrm{gal}\end{array}$ \\
\hline & $\begin{array}{l}\text { In field wastewater } \\
\text { collection with gas } \\
\text { powered pumps and } \\
\text { storage }\end{array}$ & In field & Wastewater & $1600 \mathrm{gal}$ \\
\hline \multirow[t]{7}{*}{ 3. POL Storage } & $\begin{array}{l}\text { Phase I - mobile } \\
\text { facility in stationary } \\
\text { mode }\end{array}$ & $\begin{array}{l}\text { Staging } \\
\text { Area }\end{array}$ & $\begin{array}{l}\text { Diesel fuel; } \\
\text { Various lubricating oils, } \\
\text { hydraulic fluids; Antifreeze; } \\
\text { Brake/transmission fluid }\end{array}$ & $\begin{array}{r}2500 \mathrm{gal} \\
500 \mathrm{gal} \\
110 \mathrm{gal} \\
110 \mathrm{gal}\end{array}$ \\
\hline & $\begin{array}{l}\text { Phase I - diesel } \\
\text { storage for electric } \\
\text { generator }\end{array}$ & $\begin{array}{l}\text { Staging } \\
\text { Area }\end{array}$ & Diesel fuel & $250 \mathrm{gal}$ \\
\hline & $\begin{array}{l}\text { Phase I - gasoline } \\
\text { storage for field } \\
\text { pumps }\end{array}$ & $\begin{array}{l}\text { Staging } \\
\text { Area }\end{array}$ & $\begin{array}{l}\text { Gasoline; } \\
\text { Oil }\end{array}$ & $\begin{array}{r}100 \mathrm{gal} \\
10 \mathrm{gal}\end{array}$ \\
\hline & $\begin{array}{l}\text { Phase II - mobile } \\
\text { facility in-stationary } \\
\text { mode or temporary }\end{array}$ & $\begin{array}{l}\text { Staging } \\
\text { Area }\end{array}$ & $\begin{array}{l}\text { Diesel fuel; } \\
\text { Lubricating oils, hydraulic } \\
\text { fluids; Antifreeze; }\end{array}$ & $\begin{array}{r}5000 \mathrm{gal} \\
500 \mathrm{gal}\end{array}$ \\
\hline & fixed depot & & Brake/transmission fluid & $\begin{array}{l}110 \mathrm{gal} \\
110 \mathrm{gal}\end{array}$ \\
\hline & $\begin{array}{l}\text { Phase II - diesel } \\
\text { storage for generator }\end{array}$ & $\begin{array}{l}\text { Staging } \\
\text { Area }\end{array}$ & Diesel fuel & $250 \mathrm{gal}$ \\
\hline & $\begin{array}{l}\text { Phase II - gasoline } \\
\text { storage for pumps }\end{array}$ & $\begin{array}{l}\text { Staging } \\
\text { Area }\end{array}$ & $\begin{array}{l}\text { Gasoline; } \\
\text { Oil }\end{array}$ & $\begin{array}{r}100 \mathrm{gal} \\
10 \mathrm{gal}\end{array}$ \\
\hline \multirow[t]{3}{*}{ 4. POL Transfers } & $\begin{array}{l}\text { Fueling/Servicing of } \\
\text { Trucks or equipment; } \\
\text { loading and unloading } \\
\text { operations at Phase II } \\
\text { Depot }\end{array}$ & $\begin{array}{l}\text { Staging* } \\
\text { Area }\end{array}$ & $\begin{array}{l}\text { Diesel fuel; } \\
\text { Lubricating oils, } \\
\text { hydraulic fluids; } \\
\text { Antifreeze; } \\
\text { Brake/transmission fluids }\end{array}$ & See Item 3 \\
\hline & $\begin{array}{l}\text { Fueling/Servicing } \\
\text { generator }\end{array}$ & $\begin{array}{l}\text { Staging } \\
\text { Area }\end{array}$ & $\begin{array}{l}\text { Diesel fuel } \\
\text { Oil }\end{array}$ & $\begin{array}{r}50 \mathrm{gal} \\
<10 \mathrm{gal}\end{array}$ \\
\hline & $\begin{array}{l}\text { Fueling/Servicing } \\
\text { pumps }\end{array}$ & In field & $\begin{array}{l}\text { Gasoline } \\
\text { Oil }\end{array}$ & $\begin{array}{l}<10 \mathrm{gal} \\
<1 \mathrm{gal}\end{array}$ \\
\hline
\end{tabular}


B-12

Table 2.1 (continued)

\begin{tabular}{|c|c|c|c|c|}
\hline $\begin{array}{l}\text { Activity/Area of } \\
\text { Concem }\end{array}$ & $\begin{array}{l}\text { Potential Spill } \\
\text { Source }\end{array}$ & Location & Type of Material & $\begin{array}{l}\text { Potential } \\
\text { Quantity } \\
\text { Released }\end{array}$ \\
\hline $\begin{array}{l}\text { 5. Field } \\
\text { Maintenance } \\
\text { Operations }\end{array}$ & $\begin{array}{l}\text { Storage and Use of } \\
\text { small quantities of } \\
\text { solvents }\end{array}$ & $\begin{array}{l}\text { Staging } \\
\text { Area }\end{array}$ & $\begin{array}{l}\text { Napthas; non-halogenated } \\
\text { hydrocarbon solvents; } \\
\text { Alkaline soaps }\end{array}$ & $\begin{array}{l}55 \mathrm{gal} \\
55 \mathrm{gal}\end{array}$ \\
\hline \multirow[t]{3}{*}{$\begin{array}{l}\text { ewater } \\
\text { ction and }\end{array}$} & $\begin{array}{l}\text { Transport of Field } \\
\text { Storage Tanks }\end{array}$ & In field & Wastewater & $1600 \mathrm{gal}$ \\
\hline & Soil Drying & $\begin{array}{l}\text { Staging } \\
\text { Area }\end{array}$ & Wastewater & See below \\
\hline & $\begin{array}{l}\text { Collection and } \\
\text { Treatment }\end{array}$ & $\begin{array}{l}\text { Staging } \\
\text { Area }\end{array}$ & $\begin{array}{l}\text { Wastewater, } \\
\text { Gas/oil }\end{array}$ & $\begin{array}{r}5000 \mathrm{gal} \\
10 \mathrm{gal}\end{array}$ \\
\hline $\begin{array}{l}\text { 7. Hazardous } \\
\text { Waste } \\
\text { Accumulation }\end{array}$ & $\begin{array}{l}\text { Container } \\
\text { Accumulation } \\
\text { loading/unloading }\end{array}$ & $\begin{array}{l}\text { Staging } \\
\text { Area }\end{array}$ & Unknown & $55-550 \mathrm{gal}$ \\
\hline \multirow[t]{2}{*}{$\begin{array}{l}\text { 8. Staging/Storage } \\
\text { of Excavated } \\
\text { Soil and Debris }\end{array}$} & $\begin{array}{l}\text { Storage; loading and } \\
\text { unloading operations }\end{array}$ & $\begin{array}{c}\text { Staging } \\
\text { Area }\end{array}$ & $\begin{array}{l}\text { Soil, landscaping wastes, } \\
\text { debris }\end{array}$ & $4000 \mathrm{ft}^{3}$ \\
\hline & $\begin{array}{l}\text { Precipitation } \\
\text { generated leachate }\end{array}$ & $\begin{array}{l}\text { Staging } \\
\text { Area }\end{array}$ & Leachate & Unknown \\
\hline \multirow{3}{*}{$\begin{array}{l}\text { 9. Staging of } \\
\text { Remedial } \\
\text { Materials }\end{array}$} & Container/Bin failure & $\begin{array}{l}\text { Staging } \\
\text { Area }\end{array}$ & $\begin{array}{l}\text { Fertilizer, } \\
\text { Lime }\end{array}$ & $\begin{array}{r}2000 \mathrm{lbs} \\
10000 \mathrm{lbs}\end{array}$ \\
\hline & Loading/Unloading & $\begin{array}{c}\text { Staging } \\
\text { Area }\end{array}$ & Same as Above & $\begin{array}{r}\text { Same As } \\
\text { Above }\end{array}$ \\
\hline & $\begin{array}{l}\text { Precipitation } \\
\text { Generated Leachate }\end{array}$ & $\begin{array}{l}\text { Staging } \\
\text { Area }\end{array}$ & Leachate & Unknown \\
\hline
\end{tabular}

* Fuel transfers to excavation equipment will be performed in temporary CRZs located along the exclusion zone perimeter on an as needed basis. 


\subsection{SPILL PREVENTION MEASURES}

This section provides minimum design and operating standards for spill prevention for the POL product, hazardous material, hazardous waste and wastewater accumulation/storage locations identified in Table 2.1. Spill prevention requirements for the materials handling and transfer operations identified in Table 2.1 are also provided. The following general spill prevention techniques shall be implemented for all materials storage, handling and transfer operations.

- Neat and orderly storage of all POL products, fuels, chemicals, and wastes shall be maintained.

- Materials of construction used for storage containers or tanks, piping, and transfer equipment shall be compatible with the material being handled.

- Containers and tanks used for storage of POL products, hazardous materials, wastewater, and wastes shall be in structurally sound condition.

- Precautions shall be taken to prevent spillage during transfer operations. Written procedures or checklists shall be developed and followed for all large volume material transfers.

- Periodic maintenance programs shall be implemented for all tank systems, material handling, and transport equipment.

- Periodic inspections shall be performed of all POL product, hazardous material, hazardous waste, and wastewater storage locations.

- All personnel involved in handling hazardous materials, POL products, wastewater or wastes shall trained in the requirements of this plan as specified in Chap. 4.

\subsubsection{Spill Prevention Measures for Storage and Dispensing of POL Products and Hazardous Materials from Containers}

This section specifies minimum requirements and recommended practices for container storage of POL products and hazardous materials. Mobile lubrication and servicing facilities (oilers) shall meet the requirements of this section when operating in the stationary mode.

1. Containers used for POL product and hazardous material storage shall be compatible with and meet the relevant Department of Transportation (DOT) container specifications for the material held in the container. Hazardous materials and POL products shall be retained in their original shipping container unless that container is damaged, leaking, or deteriorated.

2. Containers used for POL product and hazardous materials storage shall be maintained in good condition. Containers used for storage of these materials must not have bulging heads or significant dents, creases, or corrosion. Materials received in deteriorated or damaged containers must be transferred to an equivalent DOT container that is in sound condition or rejected upon arrival.

3. Containers must remain closed except for product removal. Product removal shall be accomplished by drum pumps or horizontal storage of the container with a ball or gate valve assembly inserted in the container bungs. Small volume transfers from containers of $\boldsymbol{5}$ gal volume may be performed manually using a funnel affixed to the receiving vessel. 
4. Containers that are tapped for product delivery and stored in horizontal drum racks shall not be stacked. Drip pans with a volumetric capacity equal to $10 \%$ of the stored volume shall be provided for all containers used for product transfers. Separate drip pans shall be provided for each different substance. The materials of construction of the valve assembly shall be compatible with the material being handled.

5. Prior to any material transfer, all connections such as hoses attached to drum pumps or the lid/hose assembly of gas cans shall be checked for tightness of fit. The available capacity in the receiving vessel shall be determined.

6. Containers used for storage of POL products and hazardous materials shall be clearly marked to identify their contents. Bulk storage areas shall be posted with an National Fire Protection Association (NFPA) hazard diamond. Mobile facilities operating in the stationary mode (i.e., oilers/fuelers) and any fixed storage areas holding ignitable materials shall be posted to exclude smoking and sources of heat, sparks, or open flame.

7. All POL product storage areas and mobile facilities in the stationary mode shall be located 50 feet from any potential ignition or electrical source. Electrical powered equipment used for product delivery shall meet the relevant NFPA and National Electrical Code (NEC) Class I Division I standards.

8. Containers holding volatile POL products (i.e., diesel fuel, gasoline) shall be protected from radiant heat, direct sunlight, and precipitation by use of tarps, temporary roofed structures (tents) etc. Containers shall be elevated (placement on pallets, racks, etc.) to minimize contact with standing precipitation, area run-on, spills or other free standing liquids.

9. Bulk containers ( $>5 \mathrm{gal}$ ) of POL products and hazardous materials shall be stored on pallets or in drum racks and properly secured. No more than four 55-gal containers should be placed on a single pallet. Bulk containers of these products shall not be stacked and shall not be accumulated in a single pile of greater than $500 \mathrm{gal}$. Small volume containers ( $<5 \mathrm{gal}$ ) of these products used for short term storage or transfer operations shall be stored in the manner described in paragraph 11 .

10. Containers must be stored in an organized manner that does not interfere with inspections, normal or emergency access, or areas required for vehicular (forklift) traffic. Containers shall be stored in rows of similar materials separated by a minimum aisle space of $3 \mathrm{ft}$.

11. Gas cans and small volume containers used for short term storage of fuel or oil shall be of $<5$ gal volume and meet the requirements of NFPA 30 . Such cans shall be stored in fire cabinets meeting NFPA standards and the cabinet shall be provided with secondary containment as specified in Sect. 2.3.1. No more than 50 gal of fuel and oil may be stored in a single cabinet. Where more than one cabinet is used for storage of these materials, the cabinets shall be separated from one another by a minimum of $10 \mathrm{ft}$.

12. Single containers of greater than 5 gal capacity shall be moved by drum-dolly or forklift using a drum handling fixture. Containers transported on pallets shall be tightly secured prior to transport. Vertical stacking of containers on pallets for transport is prohibited.

13. Containers shall be inspected prior to transport to ensure that the containers are in sound condition, that bungs are tightly closed, and that the container is secured by positive means for transport. Containers shall be tightly closed during transport. 
14. During the stationary servicing mode, mobile facilities shall be parked with their ignition off, parking brake on and the vehicle shall be secured in place by wheel chocks or other form of barrier.

15. Incompatible materials shall be stored in separate locations segregated by temporary diking.

16. Container storage areas for hazardous materials and POL products shall be inspected weekly. Inspection records that specify the date of inspection, inspector's name, items inspected, problems found, and corrective actions taken shall be maintained.

\subsubsection{Spill Prevention Measures for the Tank Storage of POL Products}

This section specifies requirements for tank storage of POL products in temporary fixed facilities (depot type storage) and mobile facilities operating in the stationary mode (i.e., fuelers). Requirements specified in paragraphs 1-10 are specific to tank storage of POL products in temporary fixed facilities and do not apply to mobile facilities operating in the stationary mode. It is currently anticipated that the Phase II subcontractor will not elect to establish temporary fixed facilities for tank storage of POL products and, therefore the requirements of Paragraphs 1-10 may not apply. Requirements specified in Paragraphs 11-13 apply only to mobile facilities. Unless otherwise noted, all other requirements of this section apply to both temporary fixed facilities and mobile facilities when operating in the stationary mode.

1. Tank storage of POL product in temporary fixed facilities shall be located aboveground. (Inground, on-ground and below ground tank storage of POL products is prohibited for this project). Temporary fixed facility POL storage tanks shall be designed to conform with the requirements of 29 CFR 1910.106 and NFPA 30.

2. Storage tanks for POL products in temporary fixed facilities (Phase II fuel depot) shall be placed upon a tank stand, saddle, or concrete base ring. The underlying base shall be constructed to prevent settlement and subsidence as indicated by the Remedial Design Division 2 specifications. Tank supports (concrete base ring, saddles, stands and securing members) shall be designed for the compressive loads, turn-over moments, and sheer stresses exerted by the tank and its contents under normal and seismic event conditions.

3. POL tanks constructed from carbon steel and stainless steels shall have the minimum wall thickness specified by Underwriters' Laboratories, Inc. (UL) Standard 142. Fiberglass reinforced plastic (FRP) tanks shall have the minimum wall thickness specified by American Society for Testing and Materials (ASTM) Standard D3299.

4. Temporary fixed facility POL storage tanks shall be provided with the normal vent capacity specified by UL142 and API Standard 2000 . This vent shall be a normally closed device. Temporary fixed facility POL tanks shall also be provided with an emergency relief vent with a venting capacity as specified by NFPA 30 .

5. Above-ground piping shall be properly supported in piping racks designed to minimize abrasion and corrosion and allow for expansion and contraction. Contact between piping and supports shall be electrically isolated, as necessary, to prevent galvanic corrosion.

6. All components of the tank system shall be compatible with the materials stored therein. All materials used in valves, fittings, piping joints, and other ancillary equipment including gaskets and seals shall be compatible with the stored materials. 
7. All tank system components shall be designed and operated to ensure corrosion resistance of the inner and outer walls of the components. Prior to installation of a temporary, fixed POL tank system, a corrosion assessment must be performed and documented.

8. All internal and external appurtenances, fittings, valves, and piping attached to a tank shall be constructed from the same material as the tank walls or from non-conducting materials to prevent galvanic corrosion. All fittings, valves, joints, and piping sections within a piping run shall be constructed from the same material. Where coupling of dissimilar metals cannot be avoided, the components shall be electrically isolated.

9. After installation of any temporary fixed POL tank and its associated piping, the system shall be hydrostatically tested before being placed into service. The results of this tightness test shall be documented and submitted to the Construction Manager (CM) for approval.

10. All temporary fixed facility POL tanks shall be provided with high and low level control systems interlocked to the feed and/or discharge pumps to activate automatic shut-off. A level indictor system separate from the level control switches is recommended. A manual on/off switch shall be provided for all transfer pumps to shut off flow in the event of failure of the automated control system.

11. Mobile POL facilities shall conform with all relevant DOT regulations (49 CFR 178.345) and the requirements of NFPA Standard 385 and/or Standard 386 concerning the storage tank's materials of construction; structural integrity and wall thickness; product delivery system; vents pressure reliefs and drains; electrical system and instrumentation and controls.

12. Owners of mobile POL facilities shall provide documentation of periodic inspections of the unit during the preceding three months, before beginning any field servicing operations. Owners of mobile POL facilities shall also provide copies of their pre-operational checklists to the $\mathrm{CM}$ before entry to the field.

13. Owners of mobile POL facilities shall provide certification concerning the integrity and tightness of the cargo tank and elements of the product delivery system (pipes, hoses, pumps) before entry to the field. Such certification may be made by providing copies of the results from the most recent hydrostatic or pneumatic tests as required by DOT regulations (49 CFR 178.345-13 and 49 CFR).

14. The refueler will position the transfer vehicle in such a manner to prevent stress on components during connection and fuel transfer. Transfer lines and hoses shall not be stretched beyond their normal reach. Hoses shall be free of kinks and tangles prior to the dispensing of products. Hoses shall be continuously supported by the ground surface or by temporary hose supports at a spacial distance that will prevent overstressing the hose and end connections.

15. While pumps and/or motors are in operation the refueler will check for unusual noise or vibration, overheating, and leaks.

16. A flexible grounding cable or ground reel shall be installed on the off-loading header.

17. Pressure or flow loss monitoring switches shall be provided in the discharge piping of all transfer pumps. Flow rate and flow totalizing indicators shall be present in the transfer lines.

18. Inlet and outlet piping on POL tanks should be provided with check valves in the individual lines. 
19. Prior to receiving and transfer operations, the level and capacity in all POL tanks, fuel trucks, and the receiving unit (i.e. transport trucks, heavy equipment) shall be determined and recorded. Total volume transferred or available capacity shall be checked and recorded during transfer operations.

20. Prior to beginning any material transfer operation, all fittings, transfer lines, and connections shall be inspected for tightness of fit, signs of leakage, or degradation. During fueling operations to heavy equipment or transport trucks, the receiving vehicle will be secured with its parking brake set and the engine off. An interlocked warning light system or physical barrier shall be used to prevent vehicular departure prior to complete disconnection of transfer lines. These positive controls shall also be applied to the mobile fueling vehicle during such operations.

21. Prior to departure of any fuel truck, the lowest most drain and all outlets shall be examined for leakage.

22. Temporary connections for POL transfer, and fueling operations shall be made with dry disconnects. Alternately, such connections may be made using quick disconnects where a ball valve is adjacent to the camlock in the transfer line.

23. All mobile fueling tanks and temporary fixed POL tanks shall be periodically inspected. All externally accessible portions of a POL tank (i.e., walls, seams, roof, foundation) and ancillary equipment (above-ground piping, valves, fittings, flanges, pipe supports, control systems, pumps, etc.) shall be inspected weekly (mobile facilities shall be inspected upon each setup). Results of inspections shall be recorded on the provided checklist or equivalent form.

24. Control system components (i.e., level indicators, level controls, flow-metering instruments) shall be calibrated before the initial use and quarterly thereafter.

25. All POL product tanks shall be marked to identify their contents and with an NFPA hazard diamond. Signs to exclude potential ignition sources (i.e., smoking) shall be posted in the vicinity of both fixed and mobile tanks in the stationary mode.

26. POL tanks shall be segregated from potential ignition sources such as electrical systems, open flame, and maintenance operations by a minimum distance of $50 \mathrm{ft}$. Electrical driven equipment for fueling operations shall meet NEC Class I Division requirements.

27. Upon completion of each fueling operation, all dispensing equipment and hoses shall be stored and secured before departure of the receiving equipment, all appropriate valves shall be closed and all electrical controls shall be returned to non-delivery status. The operator will clean regularly at and below connections and look for fuel residue accumulation on surfaces below connections and fittings. The vehicle operator shall perform an inspection before departure to ensure that all connections have been broken and that the hoses are properly secured.

28. No servicing operation will take place when an electrical storm is within three miles of the area. Servicing operations are defined as any movement of fuel, oil, or any other flammable or combustibles liquids.

29. A two person policy is required for all large volume ( $>5-10 \mathrm{gal})$ fuel handling operations. During fueling, operators must monitor the receipt and observe for leaks throughout the operation. 


\subsubsection{Spill Prevention Measures for Wastewater Management Activities}

This section provides design and operating standards to prevent spills from wastewater management activities during the LEFPC remedial action. The activities covered by the requirements of this section include (1) in-field collection and storage of excavation infiltration water and decontamination wastewater (2) transport of those waste waters to the treatment system, (3) collection and storage of wastewater generated from soil drying (4) collection and storage of prescrub wastewater from decontamination of sampling equipment and (5) wastewater treatment. For the purposes of this section, portable tanks used to accumulate wastewater from excavation dewatering and field decontamination are referred to as collection tanks and those used for equalization/storage at the head end of the treatment system are referred to as wastewater storage tanks. Tanks used for accumulation/storage of wastewater from personal use activities, sampling equipment cleaning subsequent to the pre-scrub step and storage of treatment system effluents meeting permit discharge limits are not subject to the requirements of this section.

1. A phase separation box may be used for wastewater storage at the head end of the treatment system. The unit shall have a minimum sidewall and bottom wall thickness of 0.167 in. and 0.25 in., respectively.

2. Any wastewater storage tank, other than a phase separation box that is constructed from carbon steel or stainless steels shall have the minimum wall thickness specified by UL Standard 142. Any wastewater collection or storage tank constructed from FRP shall have the minimum wall thickness specified by ASTM Standard D3299.

3. The allowable wall thickness for wastewater collection and storage tanks constructed from polyvinylchloride (PVC), high-density polyethylene (HDPE) or polypropylene shall be a minimum of 0.25 in for tanks of $<1000$ gal capacity and a minimum of 0.375 in for tanks of 1000-2000 gal capacity. The construction contractor shall provide data demonstrating adequate wall thickness for any tank constructed from these materials with a capacity of $>2000$ gal.

4. All vessels with anticipated operating pressures of $>15$ psig shall conform to the requirements of Sect. VIII of the American Society of Mechanical Engineers (ASME) boiler and pressure vessel code.

5. All tank system components shall be designed and operated to ensure corrosion resistance of the inner and outer walls of the components. Prior to use of any Phase $\Pi$ wastewater storage tank system, an assessment must be performed that considers compatibility with the stored material, atmospheric corrosion conditions and soil conditions, if necessary.

6. Corrosion protection shall be provided for any portion of a Phase II wastewater storage tank system or piping that contacts the soil by one of the following methods:

- Use of corrosion-resistant materials of construction such as FRP, high density polyethylene, poly-vinylidene fluoride, etc.

- Application of corrosion-resistant coatings coupled with cathodic protection. External coatings shall be tested for thickness and integrity of the application.

- Cathodic protection by sacrificial anodes or impressed current system. 
7. Wastewater tanks shall be properly supported by an underlying base that prevents settlement and subsidence as indicated by the Remedial Design Division 2 specifications.

8. Prior to the use of any wastewater tank, a tightness test (by volumetric or non-volumetric means) shall be performed that demonstrates the vessels integrity. The results of such tests shall be documented and provided to the $\mathrm{CM}$.

9. Above-ground piping and hoses shall be properly supported in piping racks or by another means that minimizes vibration, abrasion, and corrosion and allows for expansion and contraction. Contact between piping and supports shall be electrically isolated, as necessary, to prevent galvanic corrosion.

10. All components of the wastewater storage tank system shall be compatible with the materials stored therein. All materials used in valves, fittings, piping joints, and other ancillary equipment including gaskets and seals shall be compatible with the stored materials.

11. All internal and external appurtenances, fittings, valves, and piping attached to a tank shall be constructed from the same material as the tank walls or from non-corroding materials to prevent galvanic corrosion.

12. Open head wastewater collection and storage tanks shall be operated in a manner that maintains a minimum of $2 \mathrm{ft}$ of freeboard (outage). Closed head wastewater collection tanks shall be operated in a manner that maintains $1 \mathrm{ft}$. of outage.

13. Tanks used for in-the-field wastewater collection shall be provided with a visual high level indicator system.

14. Pressure or flow loss monitoring switches shall be provided in the discharge lines of all pumps used for the transfer of wastewater into or through the treatment system.

15. Inlet and outlet lines for wastewater collection and storage tanks and the treatment system shall be provided with check valves as appropriate, to prevent backflow conditions.

16. Prior to transfer operations, the level and available capacity in all wastewater collection and/or storage tanks shall be determined and recorded. Total volume transferred or available capacity shall be checked and recorded periodically during transfer operations.

17. Prior to beginning any wastewater transfer operation, all fittings, transfer lines, and connections shall be inspected for tightness of fit, signs of leakage, or degradation.

18. Temporary connections for wastewater transfer operations shall be made with dry disconnects. Alternately, such connections may be made using quick disconnects where a ball valve is adjacent to the camlock in the transfer line.

19. All externally accessible portions of any wastewater collection, storage or equalization tank (i.e., wall, seams, roof, foundation) and ancillary equipment (above-ground piping, valves, fittings, flanges, pipe supports, control systems, pumps, etc.) shall be inspected on weekly basis. Results of inspections shall be recorded and maintained.

20. Control system components (i.e., level indicators, level controls, flow-metering instruments) shall be calibrated before their initial use and quarterly thereafter. 
21. Containers used to accumulate pre-scrub wastewater shall meet the requirements of Sect. 2.2.4, Paragraphs 1, 2, 4, 7, 9, 10,11,12, 13, 14 and 15.

22. Portable wastewater tanks shall be maintained in good condition and shall be free of bulging heads, creases, dents or cracks. Portable tanks with structural defects shall be removed from service.

23. Portable wastewater collection tanks staged for transfer of influent to the treatment system shall be stored in an organized manner that does not interfere with vehicular traffic, inspection or emergency access.

24. Portable wastewater tanks shall be stored on pallets or skids. Portable wastewater tanks shall be inspected prior to transport to ensure that connections have been broken and verify the absence of leakage. Wastewater poly tanks shall be closed and secured to the forklift or truck by positive means during transport.

25. An operating procedure, incorporating the relevant requirements of this section, shall be developed for field operation of the wastewater treatment system.

26. All control systems and in-line I/C shall be calibrated before each field set-up of the system. All components of the wastewater treatment system shall be inspected daily. Results of these inspections shall be recorded on the provided checklist or similar form.

\subsubsection{Spill Prevention Measures for Accumulation of Hazardous Wastes}

Although excavation and restoration activities conducted in the LEFPC OU will not directly generate any hazardous wastes, there is some possibility that limited quantities of such wastes may be encountered during remediation. Additionally, limited quantities of such wastes may result from cleaning up spills of fuels or other POL products and from on-site maintenance and analytical activities. If generated, such wastes would be managed on-site in either satellite ( $<5$ gal) or 90 -day accumulation areas before being disposed to an offsite hazardous waste treatment, storage, and disposal facility (TSDF). Any hazardous waste accumulation within the AOC shall be performed in containers. Accordingly, this section specifies minimum requirements and recommended practices for spill prevention in accumulation areas that manage hazardous wastes or used oil in containers.

1. Containers used for hazardous waste accumulation must be compatible with the waste and meet all relevant DOT specifications for the primary constituents.

2. Containers used for accumulation of waste must remain in good condition. Waste containers must be free of significant dents, creases, corrosion, bulged heads or pitting. Containers must be free of external spillage. Waste that is accumulated in a container that leaks or exhibits deterioration must be transferred to an equivalent DOT-approved container in sound condition.

3. Containers stamped with the specification single-trip container may be used for accumulation of waste if the container is leak tested by filling with water for 24 hours before use as an accumulation container. Containers stamped as nonreturnable containers may be used for waste accumulation if hydrostatically tested.

4. Containers used to accumulate hazardous waste must remain closed at all times except during placement of the waste. Waste transfers shall be performed using drum pumps or other means to prevent spillage. Transfers of small quantities may be performed manually using funnels. If funnels are used to facilitate waste transfer, the funnel must be removed upon completion of the 
transfer operation, or screw type funnels with fusible-link latch-type lids must be used. Sparkproof bung wrenches shall be used to open or close container bungs on all containers that hold ignitable wastes or solvents.

5. Containers used for waste accumulation shall be stenciled with the words "hazardous waste." Additionally, a completed hazardous waste warning label that indicates the contents, DOT shipping code, and Environmental Protection Agency (EPA) waste code shall be affixed to the sidewall of the drum during accumulation. For containers in 90-day accumulation sites, the hazardous waste warning label must also have the date the waste was first placed in the container or the date the container was filled at a hazardous waste accumulation point.

6. Containers used to accumulate volatiles (i.e., waste, fuel, oil or spent solvents) shall be protected from direct sunlight, radiant heat, and precipitation by means of a tarp, temporary roof, drum covers etc. A minimum of 2 inches of outage shall be maintained in all hazardous waste containers.

7. Containers of hazardous waste shall be stored on pallets or similar devices that minimize (prevent) contact of the container bottom with standing precipitation, area run-on/run-off, spills or other free standing liquids. No more than four 55 gallon drums shall be stored on a single pallet. Containers holding hazardous wastes shall not be stacked.

8. Incompatible wastes shall not be placed in the same container. Incompatible wastes that are accumulated at the same location must be segregated by dikes.

9. Hazardous wastes shall be stored a minimum of $100 \mathrm{ft}$ from the site boundaries and EFPC.

10. Containers shall be inspected prior to transport to ensure the container is in sound condition, tightly closed, and secured by positive means for transport.

11. Hazardous waste containers shall be moved one container at a time by drum dollies, forklifts using a drum handling fixture, or similar means. Containers shall be secured during movement to, from or within the accumulation area.

12. Prior to any waste transfer, all connections such as hoses attached to drum pumps, shall be inspected for tightness of fit.

13. Prior to any waste transfer the available capacity in the receiving container shall be determined. Waste transfer logs that specify the type and quantity of each waste addition shall be maintained for satellite and 90-d accumulation areas. Alternately, containers may be gauged to determine available capacity prior to each waste transfer.

14. Hazardous waste accumulation areas shall be inspected on a weekly basis. These inspections shall address the container condition; evidence of spills in the surrounding area; the underlying base; and any containment system. Accumulation areas shall also be inspected after any storm events. Inspection records shall be maintained and shall specify the inspector's name; date or inspection; items to be inspected; types of problems that may occur and criteria to determine acceptability; and the date and nature of any corrective actions that were taken.

15. Hazardous waste accumulation areas shall be located a minimum of 50 feet from any potential ignition sources including but not limited to smoking, maintenance operations, power generators, convective heaters, etc. Any electrically powered device used for transfer or 
transport of ignitable or spent solvent wastes shall meet NEC Class I Division I requirements as indicated by the Remedial Design Specifications.

\subsubsection{Spill Prevention Measures for Miscellaneous Operations}

This section specifies minimum requirements and operating standards for excavation/restoration activities, staging/storage of excavated soil and debris, and staging of restoration material.

1. Prior to and at the completion of each days operation of any equipment or truck the operator or driver shall conduct a walk around inspection for leakage.

2. In the event of leakage/failure of hydraulic lines, hoses, or seals on heavy equipment in operation the operator will immediately shutdown the equipment and relieve the load from any hydraulic cylinders in compression to minimize the loss of fluids. Continued operation of the equipment will pressurize fluids causing a larger volume loss.

3. In the event of fuel line or tank ruptures, or overturns, the operator will immediately shutdown the equipment and stand clear.

4. Excavated soils may be placed in dewatering boxes prior to transfer offsite. A minimum freeboard of one-foot shall be provided to prevent spillage during transport. (Greater freeboard or outage shall be provided where the slope of the haul route increases the spill potential). The boxes shall be covered during transport or when rain is imminent.

5. Upon the completion of filling operations a walk around inspection shall be performed to ensure the leak-tightness of the boxes and to confirm the cover is properly secure.

6. The ground surface in the staging area for dewatering boxes shall be graded level and compacted to support equipment and boxes and prevent tipping/spillage caused by ground subsidence as required by the Division 2 of the remedial design specifications.

7. If soil used for restoration is staged in a pile it shall be covered with a 10-mil high-density polyethylene (HDPE) liner at all times when not in use.

8. Bulk quantities of fertilizer and lime shall be maintained in storage bins that are protected from the elements in a manner that prevents the generation of leachate from precipitation events (i.e., covered by tarps). Storage bins shall remain closed except for emptying or filling.

9. Adequate aisle and work space in the material staging areas will be provided to allow for equipment turnaround and to avoid equipment mishaps from causing a spill.

10. Good housekeeping and inspections shall be conducted to avoid the spillage of material due to degradation of preventative measures.

11. When material is lifted or moved it shall be properly secured to prevent the shifting of weight and overturning. A spotter shall be stationed during the movement of material to help prevent equipment mishaps.

12. Loading and unloading fertilizer/lime shall be conducted in a manner to minimize spillage. After each movement or transfer of material a walk around inspection shall be conducted to ensure that storage bins are properly closed, any exposed material is properly covered, and all covers properly secured. 


\subsection{SPILL CONTROL AND CONTAINMENT REQUIREMENTS}

Secondary containment is required under provisions of the Clean Water Act (CWA) and RCRA for those facilities that store POL products, hazardous substances, hazardous wastes, or used oil in quantities greater than certain thresholds or in excess of certain time limits. Under 40 CFR 112 , secondary containment is required for POL product storage in tanks with a capacity of greater than $660 \mathrm{gal}$ or for other facilities that store in excess of $1320 \mathrm{gal}$ of POL products. Secondary containment for CWA hazardous substance storage locations may be required under best management practices plans through the reference in 40 CFR 125 Subpart $K$ to the requirements of 40 CFR 112 and proposed 40 CFR 151. Additionally, secondary containment should be provided for certain non-regulated units as a matter of good engineering practice. In general secondary containment may be provided by vaults, dikes, liner systems or double walled vessels. Due to the short duration of this project, fixed secondary containment systems are inappropriate and therefore this plan focuses upon liner systems as the primary form of secondary containment.

\subsubsection{Secondary Containment Requirements for Container Storage}

The section specifies minimum requirements for secondary containment systems for container storage locations holding POL products, hazardous materials, hazardous wastes and used oil except for those operations involving only limited volumes (typically $<\mathbf{g a l}$ ). Container storage of pre-scrub wastewater from sampling equipment decontamination is also subject to these requirements. The requirements of this section also apply to mobile facilities (oilers) while in the stationary mode. Secondary containment for such facilities shall be provided by a flexible membrane liner (FML) system or port-a-berm system meeting the following requirements:

1. Secondary containment liner systems must be installed on a properly developed base. At a minimum the underlying soil sub base shall be graded smooth and compacted as required by the remedial design specifications. The underlying soil sub base shall be free of deleterious matter including but not limited to sticks, roots, rocks, chert, gravel, solid waste or other debris, vegetation, or other organic matter.

2. The liner material must be chemically resistant and impervious to the stored material for a period of 72 hours.

3. Secondary containment liner systems may consist of inflatable port-a-berms or an FML placed over earthen or half-pipe section berms that encircle the storage area. Earthen berms should be constructed from suitable clays compacted to a permeability of $<1 \times 10^{-6} \mathrm{~cm} / \mathrm{s}$.

4. Secondary containment liner systems must cover all areas that may be contacted by spilled material. For liner systems with earthen berms, the liner must extend over the exterior wall of the berm and be secured by burial under a minimum of $2 \mathrm{ft}$ of compacted native soil. For liner systems using berms consisting of half pipe sections the FML shall be placed over the pipe section and secured by a suitable ballast.

5. Secondary containment liner systems shall not have cracks, gaps, holes, drains, pipe penetrations, or any other opening that may permit escape of contained liquids.

6. Secondary containment liner systems should be of sufficient thickness and strength to resist tears, punctures, or abrasion from storage of containers, foot traffic, or vehicular traffic. The recommended minimum liner thickness is $\mathbf{3 0}$ mils. 
7. Incompatible materials shall not be stored within the same liner system.

8. Secondary containment liner systems shall have a containment capacity equal to $10 \%$ of the stored volume. The volume displaced by the containers must be subtracted from the system's available volume for determining capacity requirements. Additional capacity shall be provided for the amount of precipitation resulting from a 10 year, 24 hour event unless the storage unit is roofed.

9. Mobile facilities in the stationary mode and container storage or accumulation facilities for POL products, hazardous wastes and used oil shall be located a minimum of $100 \mathrm{ft}$ from LEFPC, delineated wetlands or any wet weather channel. Such facilities shall be located a minimum of $50 \mathrm{ft}$ from any electrical sources (excluding product transfer equipment meeting NEC Class I Division I requirements).

10. Secondary containment systems shall be inspected weekly or upon each use. The results of such inspections shall be documented on the attached checklist or equivalent form.

11. Free standing liquids within the containment system shall not be discharged until the absence of contamination has been verified by inspection or sampling and the discharge has been approved by the Spill Response Coordinator or Environmental Officer.

12. Secondary containment pans are recommended for storage of small volumes of POL products, solvents and reagents at locations such as on-site maintenance or analytical services operations. Such containment pans shall be constructed from compatible, impervious materials and have a capacity equal to the volume of the largest container stored therein. Incompatible materials shall not be stored in the same containment pan. Fire cabinets used for the storage of small quantities of fuels other POL products or solvents shall be located within secondary containment meeting the requirements of this section.

\subsubsection{Secondary Containment Requirements for Tank Systems}

This section specifies minimum requirements for secondary containment for tanks holding POL products. The requirements of this section also apply to mobile facilities (fuelers) when operating in the stationary mode except when such units are field fueling excavation equipment in temporary CRZs established along the perimeter of the exclusion zone. Secondary containment requirements for wastewater tanks are also provided in this section. The requirements of this section do not apply to treated effluents meeting discharge limits. Secondary containment for the above tank systems and mobile fueling facilities in the stationary mode shall be provided by an FML or port-a-berm system meeting the following requirements:

1. Secondary containment liner systems for temporary fixed facility POL product tanks, shall provide a containment capacity equal to $100 \%$ of the largest tank within their boundary and must cover all areas that may be potentially reached by any spilled material. Additional containment capacity sufficient to handle the precipitation anticipated to result from a 10 -year, 24-hour flood event shall be provided.

2. Secondary containment shall be provided for mobile facilities operating in the stationary mode except when such units are fueling excavation equipment in temporary CRZs located along the exclusion zone perimeter The containment capacity for such units shall equal $100 \%$ of the cargo tanks volume and must cover all areas that may be potentially reached by any spilled material. It is recommended practice to provide secondary containment with a capacity equal to the transfer volume for fueling of heavy equipment in CRZs along perimeter of the exclusion zone. 
3. Secondary containment shall be provided for wastewater collection tanks, wastewater storage tanks and the treatment system. These systems shall provide a containment capacity equal to the $10 \%$ of the volume of the subject system.

4. Secondary containment (i.e., drip pans) shall be provided for all stand-alone fuel or wastewater pumps. The containment capacity shall equal the volume of the fuel tank or oil reservoir, whichever is greater. This requirement does not apply to pumps located within the secondary containment system of an associated tank.

5. Secondary containment liner systems must be installed on a properly developed base that has been graded smooth and compacted as required by the remedial design specifications. The underlying soil base shall be free of deleterious matter including but not limited to sticks, roots, rocks, chert, gravel, solid waste or other debris, vegetation or other organic matter. It is recommended that a geotextile fabric layer be placed over the native soils and directly beneath the secondary containment liner. The base of the containment system for fueling operations and POL tanks shall be graded to provide a $1-2 \%$ slope away from LEFPC.

6. The FML material must be chemically resistant and impervious to the stored material for a period of 72 hours.

7. Secondary containment liner systems shall incorporate berms that encircle the tank system. Earthen berms shall be constructed from suitable clays compacted to a permeability of less than $1 \times 10^{-6} \mathrm{~cm} / \mathrm{s}$. The secondary containment liner should extend over the exterior wall of the berm and be secured by burial under a minimum of $2 \mathrm{ft}$ of compacted native soil or by other suitable ballast.

8. Secondary containment liner systems shall not have cracks, gaps, holes, drains, pipe penetrations, or any other opening that may permit escape of contained liquids.

9. Secondary containment liner systems should be of sufficient thickness and strength to resist tears, punctures or abrasion from storage of containers, foot traffic, or vehicular traffic. The recommended minimum liner thickness is $\mathbf{3 0}$ mils.

10. Incompatible materials shall not be stored within the same liner system.

11. Mobile facilities in the stationary mode, and POL storage tanks shall be located a minimum of $100 \mathrm{ft}$ from LEFPC or any wet weather channel. Such facilities shall be located a minimum of $50 \mathrm{ft}$ from any electrical sources (excluding product transfer equipment meeting NEC Class I Division I requirements).

12. Secondary containment systems shall be inspected daily or upon each use. The results of such inspections shall be documented.

13. Free standing liquids within the containment system shall not be discharged until the absence of contamination has been verified by inspection or sampling and the discharge has been approved by the Spill Response Coordinator or Environmental Officer. 


\section{OIL AND HAZARDOUS SUBSTANCES RESPONSE PLAN}

This Oil and Hazardous Substances Response Plan defines organizational authorities and responsibilities for preparation and implementation of response actions in the event of an oil or hazardous substance release. Conditions that cause implementation of this plan and levels of response actions that correlate with the potential risks of various emergency events are also defined. Additionally, post incident remediation and reporting requirements are identified by this plan.

\subsection{CONDITIONS OF IMPLEMENTATION}

This plan will be implemented for any release of oil, hazardous substances, hazardous wastes, or wastewater at the site or into EFPC. Any incidental or deminimus leakage or spillage $\ll 1$ gal) at the site that does not enter EFPC is not subject to this plan. This plan recognizes that the hazards associated with a release are dependent upon a number of factors including the quantity of released material, its toxicity and flammability, and the potential for the release to reach the environment. Therefore, this plan provides for two separate levels of response actions that are consistent with the degree of hazard presented by an incident.

Level 1 incidents require minimal implementation of this plan. The criteria that define Level 1 incidents are:

1. Level 1 incidents involve limited releases of oil, hazardous substances, hazardous wastes or wastewater in quantities (generally $<50$ gal) that may be readily handled within the Contractor's on-site capabilities under the direction of their Spill Response Coordinator. Minimal spillage or drippage is not considered to constitute a Level 1 incident.

2. Level 1 incidents have very limited potential to involve fire (either because the material is noncombustible or potential ignition sources are excluded).

3. Releases that exceed the reportable quantity (RQ) for the substance or reach EFPC and that can be readily handled by on-site personnel are Level 1 incidents but require compliance with Level 2 reporting procedures defined in this section and Sect. 3.3

The general response framework for Level 1 incidents involves:

1. Upon discovery of any spill or leak (except incidental spillage) that person shall notify the Construction Manager or senior individual at the site. The individual discovering the release or the Construction Manager shall notify the Spill Response Coordinator (SRC) unless the release occurs after normal working hours. Releases that occur after normal work hours shall follow Level 2 incident procedures.

2. Field crews shall implement containment and control actions within their capabilities until arrival of the SRC.

3. The SRC shall proceed to the scene to oversee containment and control actions by the on-site personnel. 
4. The SRC shall investigate the cause of the incident and evaluate the need for further response or remedial action.

Level 2 Incidents require implementation of full reporting and response actions under this plan. In general, Level 2 incidents may exceed the on-site spill response capabilities and require assistance by the HAZMAT Response Team (HRT). Any incident that reaches EFPC, involves fire or exceeds the RQ for that substance and that can not be readily controlled by on-site personnel is a Level 2 incident. The following criteria for a Level 2 incident include:

1. Level 2 incidents involve releases of oil, hazardous substances, hazardous wastes or wastewater in quantities (generally $>50 \mathrm{gal}$ ) that are not readily handled by the on-site personnel.

2. Level 2 incidents involve fires or releases to EFPC that can not be readily (quickly) contained and controlled within the capabilities of the on-site personnel and equipment.

3. Any release event or fire occurring after normal working hours is a Level 2 incident.

The general response framework for Level 2 incidents involves:

1. Upon discovery of any Level 2 incident the responsible organization or person discovering such a release shall notify the Construction Manager and SRC and initiate control activities within their capability.

2. Upon notification of a Level 2 incident the SRC shall notify the Oak Ridge Fire Department (ORFD) and Y-12 PSS.

3. The SRC shall proceed to the scene and direct response actions until arrival of the HAZMAT Response Team (HRT) of the ORFD.

4. Upon notification of a Level 2 incident, the Senior Fire Official (SFO) of the ORFD will activate the HRT and proceed to the scene.

\subsection{ORGANIZATIONAL AUTHORITIES AND RESPONSIBILITIES}

This section defines organizational responsibilities and authorities for pre-response planning and prevention, response implementation and post-response activities. Pre-response activities consist of implementation of release prevention measures and emergency response planning. Response activities include discovery, notification, incident assessment, scene management, and release control. Post-incident activities include restoration of response equipment, remediation of the incident scene, and incident reporting.

\subsubsection{Organizational Responsibilities for Pre-Response Activities}

Pre-response activities consist of implementation of release prevention and containment measures and emergency response planning. Release prevention and containment measures were previously identified in Chap. 2 of this SPR. The construction contractor has the primary responsibility for implementation of release prevention measures. Emergency response planning consists of four activities: hazards identification, vulnerability assessment, risk analysis and capability assessment. Organizational responsibilities and authorities for pre-response activities are defined below. 


\subsubsection{Construction Contractor}

1. The construction contractor shall submit to the Project Environmental Manager information concerning the type, typical quantities, and locations for storage and handling of all POL products, hazardous substances, hazardous wastes, used oil, and waste waters at the LEFPC OU. Information concerning the storage of the above materials will be updated whenever the type, quantities, or location of the stored materials change.

2. The construction contractor shall implement appropriate spill prevention and containment measures, as described in Chap. 2. of this SPR.

3. The constructor contractor shall implement an active surveillance program to ensure prompt discovery, notification, and response for any release of oil, hazardous substances, hazardous wastes, or wastewater.

4. The construction contractor shall ensure that personnel in their organization have been properly trained concerning spill notification and initial response actions.

5. The Construction Contractor's Site Safety and Health Officer (SSHO), as the designated spill response coordinator (SRC), shall ensure that on-site personnel are properly trained to respond to Level 1 incidents and identify Level 2 releases.

6. The SRC shall procure or establish plans for access to all equipment necessary for responding to Level 1 incidents. The SRC shall ensure that such equipment is maintained in ready condition.

\subsubsection{Project Environmental Manager}

1. The Project Environmental Manager shall be responsible for compiling the data provided by the construction contractor concerning the type, quantity and locations of regulated substances in the LEFPC OU into the project SPR. As part of this effort, the Project Environmental Manager shall evaluate the potential risk of release of these substances, their potential impacts on EFPC or the environment, and prescribe relevant prevention measures within the plan.

2. The Project Environmental Manager shall perform periodic assessments to ensure that the release potential identified in this plan reflects actual on-site conditions during remediation in the EFPC OU.

3. The Project Environmental Manager shall conduct periodic assessments to ensure that spill prevention and containment measures are being properly implemented and that appropriate spill control and response equipment is being maintained in ready condition.

\subsubsection{LEFPC Project Manager}

1. The LEFPC Project Manager with assistance from the Project Environmental Manager and Safety Officer shall develop cooperative agreements with local authorities (ORPD and ORFD) and LMES organizations that may respond to or remediate releases that occur at the site.

2. The LEFPC Project Manager shall ensure that the Y-12 PSS has integrated release reporting from LEFPC into their standard notification procedures. 


\subsubsection{Oak Ridge Fire Department}

1. The Oak Ridge Fire Department (ORFD), has agreed to provide the primary emergency spill response and control capability for Level 2 incidents within the normal jurisdictional authorities of their HAZMAT Response Team. The Senior Fire Officers (SFOs) shall function as the Incident Commanders (ICs) for such occurrences.

\subsubsection{Organizational Authorities and Responsibilities for Response Activities}

The response phase activities for releases of oil, hazardous materials, hazardous wastes, and wastewater include discovery, notification, incident assessment, scene management and release control. The organizational responsibilities and authorities for response activities are outlined in the remainder of this section.

\subsubsection{Construction Contractor Employees}

1. Maintain an active surveillance and monitoring program to ensure rapid discovery of any release of oil, hazardous substances, wastewater, or hazardous wastes.

2. Implement the initial notification procedure outlined in Sect. 3.3 immediately upon discovery of any release of oil, hazardous substances wastewater, or hazardous wastes. The construction manager shall be responsible for ensuring that any on-site personnel discovering such a release have properly implemented the notification procedure.

3. Isolate and stop the source of the spill (i.e., returning overturned drums to an upright position; turning off pumps, etc.) within the organization's on-site capabilities and in a manner that does not endanger personnel.

4. Implement spill containment and fire fighting measures, within the extent of the organizations capabilities. Ensure that such measures are conducted in a manner that does not jeopardize the safety or health of personnel.

5. Report to the Incident Commander (IC) upon his arrival at the scene. The on-site construction manager shall have control of the situation until the IC arrives.

\subsubsection{Incident Commander}

The Construction Contractor's Site and Health Officer shall serve as the Spill Response Coordinator (SRC) and shall serve as the Incident Commander for Level 1 Incidents. The IC for Level 2 incidents shall be the SFO of the Oak Ridge Fire Department (ORFD).

1. Upon notification of a release event or other emergency that involves this plan, the IC will immediately proceed to the scene in order to direct response actions. If the initial notification indicates that injuries have occurred, the IC shall request an ambulance service from Oak Ridge Methodist Medical Center.

2. The IC will evaluate the incident to determine the type and quantity of spilled material, extent of the release, probable routes of migration, and the potential for further degradation of the incident. This initial assessment shall also determine the magnitude of the potential threat to onsite personnel, off-site populations, and the environment. For Level 1 incidents, this assessment shall be conducted by the SRC. The SRC shall assist the SFO, as necessary, in performing this 
assessment for Level 2 incidents. Based upon this initial assessment, the IC shall determine the Incident Level in accordance with the criteria in Sect. 3.1.

3. For Level 2 incidents, the IC shall immediately activate the HAZMAT Response Team (HRT) upon receiving notification of such an occurrence.

4. The IC shall conduct a vulnerability analysis for the incident to determine potential impacts on off-site populations, establish control zones for the incident and, if necessary, define evacuation corridors.

5. If the IC's on-scene assessment determines that the incident meets Level 2 criteria, the IC shall notify the following organizations:

- the Oak Ridge Police Department, as necessary, for securing the scene and notifying/evacuating potentially impacted downstream populations,

- the Oak Ridge Publicly Owned Treatment Works (as appropriate),

- the Y-12 PSS, and

- the LMES Project Manager

For Level 1 or 2 incidents where the release has reached EFPC or is another RQ type incident, the IC shall immediately notify the Y-12 PSS and LMES Project Manager.

6. If the incident involves fire or toxic gas release, the IC will deploy fire teams to the scene.

7. In conjunction with the Oak Ridge Police Department, the IC will secure the scene and response action control zones. If necessary, the IC will coordinate with the ORPD to evacuate vulnerable zones.

8. If the incident involves or has the potential to involve fire, the IC will direct the fire teams in taking actions to exclude potential ignition sources and combustible materials from the scene of the incident and/or extinguish the fire.

9. The IC will direct the response activities of on-site personnel or the HAZMAT Response Team (HRT) as appropriate for the incident level. Examples of containment and control activities that may be undertaken include removal or isolation of leaking containers; transfer of materials from leaking containers or tanks; removal of flammable materials from the incident scene; application of dry absorbent materials or spill pillows; construction of temporary berms or placement of absorbent booms to control the spread of spilled material; diversion of spilled material from the creek by placement of booms or construction of temporary diversionary trenches; interception of spilled materials that have entered the creek by placement of booms or temporary dams; suppression of toxic or flammable vapors by application of foam or spill blankets.

10. The IC shall request assistance from other response organizations, in accordance with existing cooperative agreements, when such capabilities are required.

11. The IC shall maintain an Incident Log detailing the date, time, cause and nature of the occurrence and the actions taken during the response. 
12. The SRC shall ensure that containment and control actions are taken in a manner that does not interfere with subsequent clean-up activities.

13. The SRC shall ensure that the response actions are taken in a manner that minimizes the generation of wastes and residues within the context of the incident.

14. The IC shall determine when the release containment and control phase of the response has been completed.

15. The SRC (IC) shall ensure that all response equipment is decontaminated restored or replaced as expeditiously as possible.

\subsubsection{HAZMAT Response Team}

The HAZMAT Response Team (HRT) of the ORFD shall provide the primary containment and control capabilities for Level 2 incidents. The HRT shall conduct release containment and control actions as directed by the IC. Such measures will involve the following general types of response actions: isolating and eliminating the hazard source; removing other potential hazards from the scene; containing released material; directing released material from potential migration routes; intercepting released material that has reached potential pathways for off-site migration; and suppressing toxic or flammable vapors.

\subsubsection{Oak Ridge Fire Department}

1. Upon notification that a Level 2 incident has occurred, the Fire Department will notify the IC and activate the HRT and fire teams, as appropriate, in accordance with their standard procedures.

2. Upon request by the IC, the Fire Department shall conduct vulnerability analysis and air migration modeling to establish appropriate control zones and evacuation corridors.

3. For Level 2 incidents, the Fire Department will notify (as requested by the IC) the LMES Project Manager, Y-12 PSS, City of Oak Ridge privately owned treatment work (POTW) and downstream property owners (as appropriate).

4. At the request of the IC, the Fire Department shall assist the ORPD in the evacuation of areas determined to be within vulnerable zones.

\subsubsection{Oak Ridge Police Department}

1. Upon request by the IC, the ORPD shall proceed to the scene to secure the affected area and establish traffic controls to ensure ease of access by the HRT and ORFD.

2. Upon request by the IC, the ORPD shall assist the ORFD in the evacuation of areas within vulnerable zones.

\subsubsection{Site Safety and Health Officer/HRT Specialist}

In addition to other responsibilities delineated in this section, these individuals shall be responsible for the following activities during the response phase of the incident. 
1. The SSHO/HRT specialist as appropriate for the Incident Level shall be responsible for advising the IC concerning appropriate protection measures for response personnel;

2. As necessary, the SSHO/HRT specialist shall conduct air monitoring in the vicinity of the incident during response actions to determine potential hazards such as toxic concentrations in excess of the short-term exposure limit or flammable gas concentrations in the lower and upper explosive levels. It is anticipated that the necessary equipment for such monitoring will not be maintained on-site during the remedial effort. Therefore the SSHO shall be responsible for ensuring access to such equipment on an as-needed basis.

\subsubsection{Environmental Manager}

The Environmental Manager (EM) has the primary responsibility for ensuring regulatory compliance of those activities conducted in the LEFPC OU.

1. The EM is responsible for assisting in the evaluation of the incident and advising the LMES Project Manager and DOE whether an RQ, or other reportable incident has occurred. (as defined in 40 CFR 110, 40 CFR 265.56, 40 CFR 300, 40 CFR 302 and 40 CFR 355).

2. Upon request, the EM shall advise the IC of the pertinent regulatory requirements pertaining to the incident and response actions.

\subsubsection{Organizational Authorities and Responsibilities for Post-Incident Activities}

Post incident activities for releases of oil, hazardous materials, hazardous wastes and wastewater include clean-up/remediation of the scene; restoration of response and remediation equipment and incident reporting. Organizational responsibilities for post-incident activities are outlined below.

\subsubsection{Spill Response Coordinator}

1. The SRC has primary responsibility for the incident scene once containment and control activities have been completed by on-site personnel or the HRT. The SRC is assigned authority and responsibility for collection of released material; decontamination of structures and equipment; remediation of contaminated environmental media; and on-site staging of wastes and residues that result from the incident or restoration activities.

2. The SRC shall coordinate with the EM to determine the nature and scope of remedial actions to be implemented at the incident scene and ensure that those actions comply with Federal and state environmental laws;

3. The SRC shall perform environmental monitoring during remedial actions to ensure that safe work conditions are maintained. The SRC shall ensure that appropriate personnel protective measures are taken during incident remediation.

4. The SRC shall ensure that response, removal and decontamination equipment is restored to operational status as expeditiously as possible upon completion of remedial activities;

5. The SRC shall ensure proper accumulation of all removed material, residues, and contaminated environmental media generated during remedial activities.

6. Upon completion of the remedial activities, the SRC shall investigate the incident to determine the cause of the release and identify corrective actions to prevent its recurrence. 
7. The SRC shall record pertinent information concurring the incident in a Spill Log. Such data shall include but not be limited to the date, time, and location, of the incident, source and cause of the release, and a description of the incident and the containment/remediation actions taken.

8. The SRC shall assist the Construction Manager in implementing procedures and corrective actions to prevent recurrence of similar incidents.

\subsubsection{Spill Clean-Up Team}

1. As directed by the SRC and in accordance with their standard procedures, the Spill Clean-Up Team (SCUT) will perform all collection, removal, decontamination and remedial activities at the incident scene.

2. The SCUT shall restore response and decontamination equipment as expeditiously as possible upon completion of restoration activities.

\subsubsection{Environmental Manager}

1. The EM shall advise the SRC concerning the scope and nature of the clean-up and restoration activities to ensure proper remediation of the scene.

2. The EM shall assist the SRC, as necessary, in investigating the cause of the release and establishing corrective measures to prevent its recurrence.

3. The EM shall ensure that sampling is performed at the incident scene to delineate boundaries for the remedial effort; define decontamination requirements; ensure proper management of clean-up residues and to verify remediation of the incident scene.

4. The EM shall advise the SRC concerning regulatory requirements for the appropriate management of contaminated media and residues resulting from the clean-up activities.

5. The EM shall participate in the post-incident reporting activities as necessary.

\subsubsection{Waste Management Division}

The Waste Management Division (WMD) advises the SRC concerning proper on-site accumulation of residues and contaminated media resulting from the clean-up activities.

1. The WMD provides transport of waste materials and spill residues from the LEFPC OU to a TSDF within the Oak Ridge Reservation (ORR) (as appropriate). The WMD shall assist the SRC, as necessary, in complying with the requirements of ES/WM-10, EP-710, TDEC rules and other relevant procedures for receipt of the wastes at $\mathrm{Y}-12$.

2. The WMD shall ensure proper management of all spill clean-up wastes and residues upon their receipt at Y-12.

\subsubsection{Y-12 Plant Shift Superintendent}

1. Upon determination that an RQ or other reportable incident has occurred the Y-12 PSS shall perform the necessary regulatory notifications as described in Sect. 3.6. 


\subsubsection{DOE Program Manager/LMES Project Manager}

1. Upon notification by the EM that an RQ, threshold planning quantity (TPQ), or other reportable incident has occurred, these individuals are responsible for ensuring that the applicable regulatory reporting requirements are met.

2. The DOE Program Manager/LMES Project Manager shall oversee incident investigation and occurrence reporting.

3. The DOE Program Manager/LMES Project Manager shall coordinate with other DOE/LMES organizations, as necessary, for completion of regulatory reporting, incident investigation and development of news releases.

\subsubsection{LMES Public Relations Department}

1. The Public Relations Department shall obtain information concerning the incident and develop appropriate news releases.

\subsubsection{Construction Manager}

1. The Construction Manager shall participate in the incident investigation and subsequent occurrence reporting.

2. In conjunction with the SRC, the Construction Manager shall develop corrective measures and procedures to prevent occurrence of a similar incident. The Construction Manager shall be responsible for ensuring the implementation of such measures.

\subsection{INITIAL NOTIFICATION PROCEDURES}

This section outlines the notification and response procedures to be implemented by persons that discover a release of oil, hazardous substances, hazardous wastes, or wastewater. Minimal spillage or drippage shall be managed immediately by the on-site personnel and is not covered by this plan. In the event of a release of oil, hazardous substance, hazardous waste, or wastewater the person discovering the release shall implement the following actions.

1. Immediately notify the Construction Manager or senior individual in charge of the affected area.

2. Notify personnel in the affected area to cease operations, secure the area and restrict access. Gain the assistance of one other individual for subsequent response actions.

3. For Level 1 incidents notify the SRC using the on-site radio or mobile telephone. For Level 2 incidents the SRC shall notify the Oak Ridge Fire Department by dialing 482-8400. Report the following information:

- name of the individual reporting the incident;

- location of the spill;

- number of injured personnel and nature of the injuries (if applicable); 
- substance spilled or released;

- quantity of the spill (estimated);

- extent of area covered by spilled material;

- rate of spillage and if the release is continuing;

- time that release occurred (if known);

- whether the release has reached EFPC;

- presence of fire; and

- telephone number from which the call is being placed.

4. After notification of the SRC or the Oak Ridge Fire Department, the individuals managing the incident should attempt to isolate and stop the source of the release. Immediate source isolation measures shall be implemented only to the extent that the activities do not jeopardize the safety or health of personnel. Appropriate source isolation activities include uprighting overturned containers, transferring material from leaking containers, closing valves on product delivery lines, and turning off power on pumps.

5. Initiate containment and control measures. Spill control measures should be implemented only to the extent that such activities do not jeopardize the safety or health of responding personnel. Appropriate containment and control measures include; application of sorbent clays, polypropylene pulp, or other absorbents or placement of absorbent booms to control the spread of spilled material.

6. Report to the IC upon his arrival at the scene.

\subsection{GENERAL RESPONSE PROCEDURES}

Upon notification that a release of oil, hazardous substances, hazardous wastes or wastewater has occurred, the IC is responsible for coordination of response actions at the scene of the incident. A log of the response actions taken for each incident must be maintained by the IC and shall contain a description of the date, time, location, nature of the incident and the response actions taken. As described in Sect. 3.2.2.2, the initial activities of the IC shall be to secure the scene, conduct an assessment of the event and notify the Y-12 PSS and LMES Project Manager (for Level 2 incidents or Level 1 releases that have entered EFPC). After completion of the initial assessment and notifications, the IC shall direct on-sight personnel or the HRT in completing source isolation and containment measures. Such measures include but are not limited to:

- removal or isolation of leaking containers;

- uprighting overturned containers;

- removal of flammable materials from the incident scene;

- removal of potential ignition sources from the incident scene (i.e., restricting vehicular traffic, discontinuation of electrical power);

- removal of any incompatible materials from the area;

- depressurization of containers, tanks, or piping;

- closure of valves on product transfer lines; 
- turning off power to pumps;

- transfer of materials from leaking containers or pumps to other vessels; or

- plugging or patching leaks in containers, tanks, or piping;

- diversion of spilled material away from the creek channel by construction of temporary berms and or channels;

- placement of absorbent booms or construction of temporary dikes to confine spilled material;

- application of foam, water, or spill blankets to suppress flammable vapors;

- application of absorbent pillows, powders, or foams;

- application of water to cool the contents of tanks; and

- interception of spilled materials that have entered EFPC by construction of temporary dams from sandbags or plywood, placement of booms across the creek and/or skimming/pumping spilled material and water from the creek.

\subsection{GENERAL REMEDIATION AND RESTORATION PROCEDURES}

Upon completion of release containment and control activities by the HRT, control of the scene shall transfer from the IC to the SRC. The SRC directs the Spill Clean-Up Team in the removal and collection of released material, site decontamination and on-site staging of wastes generated from the response action. The following general remediation and restoration procedures shall be implemented in accordance with the Spill Clean Up Team standard operating procedures:

1. Prior to beginning removal and remedial measures, the SRC shall contact the EM to determine the nature and scope of the initial remedial actions and arrange for sampling.

2. The SRC shall perform environmental surveys, as necessary, to determine personal protective equipment (PPE) requirements for the SCUT and maintain safe work conditions. Such surveys shall be periodically performed during collection, removal, and remedial activities.

3. The SCUT shall remove and collect, for proper disposal, all free liquids that have been confined during the spill control activities.

4. Contaminated sorbent materials shall be collected by hand or non-sparking shovels and transferred to DOT-approved containers.

5. Impervious materials that have been contacted by the spill material shall be decontaminated. Spent decontamination solutions shall be collected and transferred to DOT-approved containers.

6. If the spilled material contacted soils, all visibly wetted or contaminated soil in the area shall be removed. The removed soil should be transferred to DOT-approved containers.

7. Upon completion of the decontamination and removal operations, the SRC shall coordinate with the Project Environmental Manager to arrange for sampling to verify completion of cleanup activities and management of spill residues. The need for further removal activities will be determined by the EM based on the sampling results. 


\subsection{RELEASE REPORTING REQUIREMENTS}

This section describes the reporting requirements that must be met for releases of oil, hazardous substances, hazardous wastes or wastewater that occur in the LEFPC OU. Immediate notification to federal, state, and local agencies will be made by the Y-12 Plant Shift Superintendent (PSS) and documented in accordance with established procedures.

1. Oil Spills. Oil sheens observed on EFPC, or other waters of the State of Tennessee are to be reported immediately by telephone to personnel at the National Response Center (NRC), Tennessee Emergency Management Agency (TEMA), Local Emergency Planning Committees (LEPCs), and the Tennessee Department of Environment and Conservation, Department of Energy, Oversight Division (TDEC/DOE-O).

2. Hazardous Substance Releases. Releases of hazardous substances equal to or greater than a reportable quantity (RQ) as identified in Title 40 CFR, Part 302 (Table 302.4) are to be reported immediately to personnel at the National Response Center (NRC), Tennessee Emergency Management Agency (TEMA), Local Emergency Planning Committees (LEPCs), and the Tennessee Department of Environment and Conservation, Department of Energy, Oversight Division (TDEC/DOE-O) when it has been determined that a RQ has been released to the environment.

3. Investigations. As soon as practical, but in not less than 72 hour, the SRC shall initiate an investigation of any incident that requires implementation of this plan. The level of investigation shall be consistent with the nature of the subject incident. The SRC may obtain the assistance of the Construction Manager, EM and other organizations, as necessary, to complete the investigation in a timely fashion. The SRC shall compile an investigation report within 10 days of the incident. An appropriate incident reporting form shall be used to compile this data. 


\section{PERSONNEL TRAINING REQUIREMENTS}

This chapter defines personnel training program requirements for implementation of this plan. Both the nature of the training course and requirements for implementation of the training program are described in this chapter.

\subsection{GENERAL SPILL PREVENTION AND RESPONSE TRAINING}

All personnel involved in the use, handling, or other management of POL products, hazardous materials, hazardous waste and wastewater shall complete an introductory spill prevention and response training program. This program shall be conducted by the SRC/SSHO and include the following elements:

- health effects associated with exposures to POL products and hazardous materials expected to be on-site;

- combustibility/reactivity of on-site materials;

- operation of instrumentation and monitoring equipment that functions as spill prevention failsafes;

- $\quad$ spill prevention procedures described by this plan;

- inspection and maintenance of containers, tanks, and fail-safe instrumentation covered by this plan;

- initial notification procedures under this plan;

- immediate spill response procedures, as appropriate;

- response organization established by this plan; and

- implementation of evacuation procedures.

In addition to the above requirements, any on-site personnel that manage hazardous waste accumulation points, handle hazardous waste, or collect samples of hazardous wastes shall complete a training program including the following elements:

- introduction to the RCRA;

- identification of hazardous wastes;

- accumulation point management;

- container use, marking, and labeling and on-site transportation;

- waste turn-in procedures.

\subsection{TRAINING PROGRAM REQUIREMENTS}

The training programs specified in Sects. 4.1 and 4.2 of this SPR will be conducted in the following manner:

- prior to starting work for on-site; 


\section{B-39}

- annually for all personnel;

- after any significant revisions to the training program or SPR; and

- after a spill response in which training deficiencies were noted.

Proper documentation of all spill prevention and hazardous waste training is required. This documentation should include, as a minimum, the student's name, job title, job description, and previous related training, instructor, test score, and projected date of annual refresher course. This information must be recorded using a locally developed form or computerized database. 


\title{
DISTRIBUTION
}

\author{
1. L. V. Asplund
}

2-3. A. K. Lee/OSTI

4. D. M. Matteo

5-6. T. J. McLaughlin

7. L. W. McMahon

8. H. C. Newsom

9. P. T. Owen

10. S. A. White

11. R. W. Weigel

12. ER Document Management Center-RC

13-14. R. M. Meccia, Foster Wheeler Environmental Corporation, 111 Union Valley Road, Oak Ridge, TN 378302

15-16. T. E. Myrick, Science Applications International Corporation, P.O. Box 2502, Oak Ridge, TN 37831

17. J. W. McCollum, MK-Ferguson of Oak Ridge Company, P.O. Box 2000, Oak Ridge, TN 37831 